\title{
Cartas desde América. La emigración de asturianos a través de la correspondencia. 1864-1925
}

\author{
JuACO LÓPEZ ÁlVAREz \\ Museo del Pueblo de Asturias. Gijón
}

\begin{abstract}
«Manuel va deciros muchas cosas, entre ellas que cuando llegue algún americano á Valdés recién desembarcado no lo critiquéis aunque esté falto de razón y muriéndose por los caminos: esto hay que verlo para creerlon.
\end{abstract}

Elena González, Habana, 25 de octubre de 1913

"Tanto tu letra como la que yo traje todabía no las cambié, porque no tube necesidad, pero como la peseta subió me conbiene el no la canjear, así que está a tu disposición para que bengas á comprar una bodega a Cuba bella, pero tienes que hacerte de cuenta que cines, teatros y juergas ya se acabaron. Nada más te digon.

Fernando Menéndez, Habana, 26 de enero de 1925

Desde 1992 el Museo del Pueblo de Asturias comenzó la tarea de formar un archivo de documentos personales, integrado por memorias, diarios, autobiografías y cartas. El archivo no sólo está destinado a los asturianos ilustres, como podrían pensar algunos, sino a cualquier asturiano que haya dejado por escrito noticias o avisos de su vida. La labor iniciada no es fácil, pues los documentos que nos interesan son de carácter privado y familiar, y es habitual que muchas personas prefieran destruirlos antes de que pasen a ser de uso público, aunque haya transcurrido mucho tiempo desde su circulación y se mantenga como norma el anonimato a la hora de publicarlos. No nos interesan los nombres, sino los contenidos de los documentos, así como la procedencia y clase social de los autores de los escritos. Hasta la fecha, el museo ha reunido un fondo documental de gran interés, en el que predomina la correspondencia de emigrantes asturianos en América.

Entre 1840 y 1940 se calcula que alrededor de trescientos mil jóvenes salieron de Asturias con destino a América. Las migraciones más numerosas sucedieron a fines del siglo $\mathrm{xIX}$ y en el primer tercio del $\mathrm{Xx}$, y se dirigieron especialmente a Cuba, Argentina y Méjico. Los muchachos marchaban con edades comprendidas entre los diez y los dieciocho años; eran 
hijos de campesinos y también de la burguesía de clase media que se desarrolló en las villas asturianas durante en el siglo XIX gracias al comercio. Muchos de estos burgueses eran emigrantes retornados que enviarán a sus hijos por el mismo camino que habían seguido ellos. Hasta fines del siglo XIX, casi la totalidad de los emigrantes serán varones, que se asientan en ciudades y trabajan en el comercio y la industria (fábricas de tabaco, textil, panaderías); a partir de aquella fecha también embarcarán muchas mozas solteras, sobre todo a Argentina, para trabajar como niñeras y criadas. Asimismo, no fueron pocas las asturianas que, casadas con emigrantes establecidos, marcharon para América con sus esposos. Las causas de todo este movimiento, uno de los más importantes de nuestra historia contemporánea, son conocidas: pobreza, expectativas de enriquecimiento, librarse del servicio militar y la guerra de África, cultura de la emigración, etc. Sus consecuencias abarcaron todos los ámbitos de la vida asturiana: la economía, la vida social y las ideas. Gracias al dinero de los emigrantes y a sus actitudes nuevas se levantaron escuelas y fuentes, se abrieron carreteras, se fundaron sindicatos agrícolas, se recuperaron fiestas y costumbres antiguas, se mejoraron las casas de los campesinos y su higiene personal, etc. Unos pocos emigrantes regresaron enriquecidos, algunos más volvieron con unos pequeños ahorros, y la mayoría se quedaron allá con situaciones económicas muy dispares, desde el multimillonario hasta el pobre vagabundo. En general, los lazos que todos ellos mantuvieron con Asturias fue a través de revistas, fotografías, noticias orales que transmitían los que iban y volvían, y sobre todo por carta.

Las cartas son una fuente de documentación muy personal y extremadamente subjetiva. Con ellas vamos a conocer la emigración utilizando unos documentos escritos por los mismos emigrantes, sin estar sometidos nada más que al dictado de su propia cultura y al de sus propios intereses. El contenido de las cartas está sujeto a varios condicionantes: primero, el temperamento del emigrante, pues hay personas que cuentan toda su vida y hay otras que carta tras carta sólo informan al destinatario de su estado de salud; segundo, el nivel de instrucción y el dominio de la escritura; tercero, el destinatario de la carta, pues no se cuenta lo mismo a un padre, un hermano o un amigo, y cuarto, el estado de ánimo del emigrante cuando escribe y sus circunstancias en ese mismo momento. En cuanto al aspecto formal de las epístolas, es un asunto que no hemos analizado, pero que tiene mucho interés para los lingüistas: el empleo de vocablos regionales, las fórmulas expresivas, la sintaxis, la ortografía, etc. (BrunetonGovernatori y Moreux 1997; Hernández 1997).

Los emigrantes dejaron escritas en sus cartas sus vivencias, sus sentimientos y su percepción de la realidad. En este sentido constituyen un 
material muy valioso, aunque puede que para algunos historiadores sea banal por considerar que ofrece una información muy subjetiva y parcial. Sin embargo, para los que nos hemos dejado influir por la antropología, estas cartas constituyen una fuente de documentación muy importante para conocer el comportamiento humano. Además, en las correspondencias utilizadas se observa una repetición de temas e intereses que demuestra el valor de esta fuente para comprender hechos más generales que trascienden las vidas aisladas de algunos individuos ${ }^{1}$.

El empleo de estos documentos personales en el estudio de las relaciones sociales procede de la sociología. Uno de los estudios pioneros y clásicos en este campo fue el publicado entre 1918 y 1920 por William I. Thomas (1863-1947) y Florian Znaniecki (1882-1958) sobre la emigración de campesinos polacos a Europa y América. Fue uno de los primeros trabajos de investigación sobre la cultura y organización social de los inmigrantes. Sus fuentes fueron la correspondencia cruzada entre los emigrantes y sus parientes de Polonia y las autobiografías escritas que solicitaron a gran número de emigrantes ${ }^{2}$. En las últimas décadas, la etnología, la historia social y la lingüística han mostrado gran interés por los documentos personales y se han publicado diversos estudios sobre la vida cotidiana basados en ellos e incluso epistolarios de campesinos, soldados y emigrantes; de estos últimos se han editado corpus de cartas en Inglaterra, Escocia, Irlanda, Alemania, Suiza y Polonia ${ }^{3}$. En Asturias, el estudio de Quirós Linares (1993) sobre la correspondencia de un emigrante en La Habana con su familia ha sido un buen comienzo para valorar todo lo que puede dar de sí esta clase de documentación.

Las cartas son para los emigrantes algo más que un envío o una llegada de noticias; son también un consuelo. Por una parte, el contar su situación constituye un desahogo muy grande. Es significativo a este respecto que en los primeros meses de la emigración las cartas que escriben

1 Esta repetición es comprensible, debido a que la biografía de muchos de los emigrantes es bastante similar, como puede verse en las que publican Constantino Suárez (1935-1959), que reseña a muchos emigrantes dedicados al periodismo y la literatura y, sobre todo, A. Barredo (1925: 23-96) y S. Monge Muley (1953: 185-671), que recogen la biografía de varios cientos de emigrantes en Cuba respectivamente.

2 Existen varias ediciones de The Polish peasant in Europe and America, la primera fue publicada por la Universidad de Chicago y la última, abreviada, en 1996, por la Universidad de Illinois. Sobre el estudio de Thomas y Znaniecki y el método de los documentos personales véase Jan Szczepanski (1978: 231-256).

3 Véase la obra dirigida por Daniel Fabre (1997), y sobre todo el artículo citado de A. Bruneton-Governatori y B. Moreux (1997: 79-103), donde aparece abundante bibliografía sobre el tema. 
sean más largas que las de años sucesivos y que se contesten rápidamente las recibidas, a los dos o tres días. Por otra parte, recibir una carta reconforta a los emigrantes; con ella llegan las palabras de cariño y el reconocimiento que se les niega en unos destinos donde durante los años de aprendizaje son menos que nada. Manuel González, dependiente de un comercio en Manguito (Cuba), escribe a su familia el 28 de abril de 1914:

Cuando tengo una carta buestra y la voy abrir, estoy nerviosísimo, porque temo traiga algo malo, pero después que la abro no ceso de cantar, hay beces que el compañero me tiene que requerir, porque los dependientes no deben cantar.

Para este trabajo vamos a emplear preferentemente las cartas de una familia del concejo de Valdés, a la que daremos el apellido de González. La familia está formada por un matrimonio y diecinueve hijos, de los que cinco murieron siendo niños. El padre era un emigrante retornado de Cuba, de donde trajo un pequeño capital que le sirvió para reformar la casa paterna y vivir con cierto desahogo; murió en 1919. La madre era mucho más joven y falleció en 1956 con noventa y cinco años. En total, diez de los hijos emigraron a Cuba, Argentina y Méjico; marcharon todos los varones y dos hijas que fueron casadas con emigrantes establecidos. Algunos no volvieron más, pero la mayoría regresaron y murieron en Asturias. A nuestros protagonistas les hemos cambiado sus nombres verdaderos, con el fin de preservar su anonimato, y son los siguientes: José, nació en 1882 y emigró a Argentina en 1899; Ramón, nació en 1886 y marchó a la vez que José para Argentina; Francisco, nació en 1888 y emigró a Argentina; Joaquín, que nació en 1899 y es el destinatario de la mayor parte de las cartas, también marchó a mediados de los años veinte, pero regresó al poco tiempo; Elena, nació en 1891 y se casó en 1913 con un primo, Antonio, que tenía negocios en Cuba, marchando para allá el mismo año de su boda; Cristina, nació en 1893 y se casó con un primo emigrante en Méjico; Pedro y Manuel, nacieron en 1897 y 1899 respectivamente, y fueron para Cuba en 1913 en compañía de su hermana Elena y bajo la custodia de su cuñado y primo Antonio; Jacinto nació en 1901 y marchó en 1920 para Cuba con el mismo Antonio, pasando después a Méjico; por último, Ángel nació en 1903 y embarcó para la Argentina en 1919.

Junto a las cartas de esta familia también utilizaremos algunas otras que nos ayudarán a comprender los temas que vamos a tratar y que son comunes a la mayoría de los emigrantes: la partida y el viaje en barco; la llegada a América y sus primeras impresiones; el trabajo y los negocios; las relaciones con otros emigrantes en América, y las relaciones con sus familiares en Asturias. No podemos entrar en biografias particulares, asun- 
to para el que las cartas constituyen una fuente de especial interés. La lectura de toda la correspondencia de un emigrante a su familia durante un periodo largo de tiempo permite conocer todos los avatares de una vida. Pero esta documentación es muy rara, pues siempre faltan cartas. Nosotros no conocemos ninguna correspondencia completa. De la familia González tenemos alrededor de cuatrocientas cartas enviadas por los hermanos emigrados a sus padres y a sus hermanos residentes en Valdés, sobre todo a Joaquín. El número es pequeño, pues sabemos que solamente en 1918 éste recibió 204 cartas de familiares y amigos.

Las cartas de América no sólo llegaban a través del servicio de correos, también era común remitirlas por medio de emigrantes de la propia familia, o de la parroquia, que venían a Asturias, y que a su regreso volvían con otras misivas. Son frecuentes las menciones a estos envíos que se realizan aprovechando el viaje de algún conocido y que a menudo incluyen productos muy diversos. En un diario de viaje escrito por un emigrante del concejo de Colunga, durante el trayecto de Buenos Aires a Asturias, entre marzo y abril de 1907, aparece la relación de los encargos

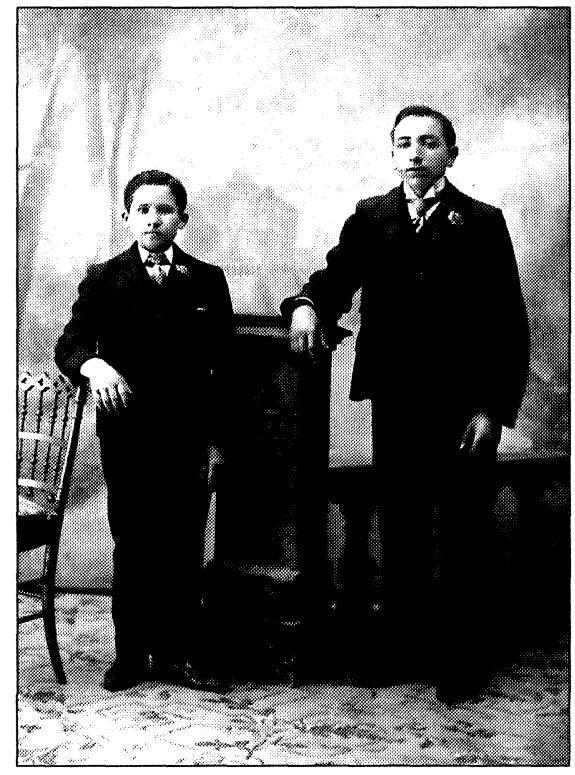

FIgURA 1.-La Americana, Retrato de dos emigrantes en Buenos Aires, 1904. Manuscrito en el reverso: Buenos Aires, Febrero / 5 / 904 / Dedico este retrato a mi / querida Madre en prueba / de cariño su querido / hijo / E. Villa. Col. Museo del Pueblo de Asturias. que traía, así como de los que llevó al volver. Trajo a Colunga los encargos de once emigrantes para repartir entre diecisiete personas, que consistían en doce cartas, seis retratos fotográficos, una postal, dos giros de 100 y 50 pesetas, unos "pañuelos y aros", y un "corte vestido" que envió una emigrante "para su familia [de] Oviedon. De regreso a Buenos Aires, en noviembre de 1907, lleva los encargos de once personas destinados a doce emigrantes: diez cartas, cuatro retratos, dos postales, nueces y avellanas para dos compañeros, un jamón, un pañuelo, un par de zapatillas, dos tarros de dulce y una "Virgen de Loreto", que es la patrona de Colunga. El intercambio de productos entre los emigrantes y sus familias es permanente. De Asturias van sobre todo productos alimenticios (embutidos, queso) y a veces revistas, periódicos y fotografías, y de 
América llegan miles de fotografías, dinero, ropa, objetos de lujo (joyas, relojes) y otros muy diversos que sirven tanto para demostrar que la casa tiene un hijo en América como para aliviar alguna necesidad apremiante. Todo este intercambio se realiza a través de los emigrantes que van y vienen, y su existencia es una buena muestra del funcionamiento de las redes de parentesco y vecindad. Un ejemplo es el texto siguiente, extraído de una carta enviada por un emigrante de Inclán (Pravia) a su hermana desde La Habana el 13 de noviembre de 1907:

Compré el braguero para papá que me costó cuatro centenes, es de metal el muelle que no se osida. No tenía por [quien enviarlo] pero ayer por la noche estubo aquí Savino el Zapatero y me dijo que se embarcaba el día 15 un yerno de el cocinero de Folgueras y que ya él havía ablado con él y que se comprometió á llebarlo. Yo no sé si lo beré para darle las gracias, porque después de todo sin conocerme ni nada se á comprometido á llebarmelo. El braguero lo tiene Savino para dárselo, así es que él llegará á Folgueras el día 30, que baya papá á recojerlo y que le pregunte si pagó derechos porque yo no sé si pagará algo.

\section{EL VIAJE Y LA LLEGADA}

Las primeras cartas de los emigrantes a América contienen la narración de su viaje. No era para menos: la partida de casa y el viaje son siempre traumáticos, y constituyen un acontecimiento excepcional para unos jóvenes que no habían salido de un área geográfica muy reducida. El primogénito de la familia González reconoce en una de sus cartas que sus "conocimientos de España y de Asturias" se reducían a una parte del concejo de Valdés y poco más:

Puede ser que esté equivocado, pero pienso que aún hoy no necesitaría ningún cicerone para recorrer todos los pueblos y rincones de mi juventud: Caroyas, Cuevas, Caneiro, Busto, Querúas, Trevías, etc. Un poquito más allá de donde solían hacer la feria, la carretera forma un recodo, ése era el sitio obligado para entregar y cobrar el ganado vendido en casi todas las ferias. Y por otra parte ahí terminaban mis conocimientos de España y de Asturias. Nunca pasé de Trevías, ni siquiera conocía la cuesta de La Espina. Del otro lado llegué hasta Navia; claro, también conocí El Chano, La Granda, Setienes, La Montaña y La Venta (Buenos Aires, 10 de noviembre de 1952).

La marcha del emigrante la conoce todo el pueblo, y algunos parientes y allegados le dan dinero y consejos antes de partir. Los preparativos eran los siguientes: arreglar la documentación necesaria, adquirir un ajuar de ropa y sacar el pasaje. Así se desprende de las notas que aparecen en un libro de cuentas de un vecino de la parroquia de Arcallana, en el 
concejo de Valdés, que envió a cuatro hijos para Cuba en 1905, 1906, 1909 y 1921. Los cuatro hermanos llevaron pasaje de tercera clase y embarcaron en el puerto de La Coruña.

Gastos de pasaje de Juan Suárez García

13 de marzo de 1909

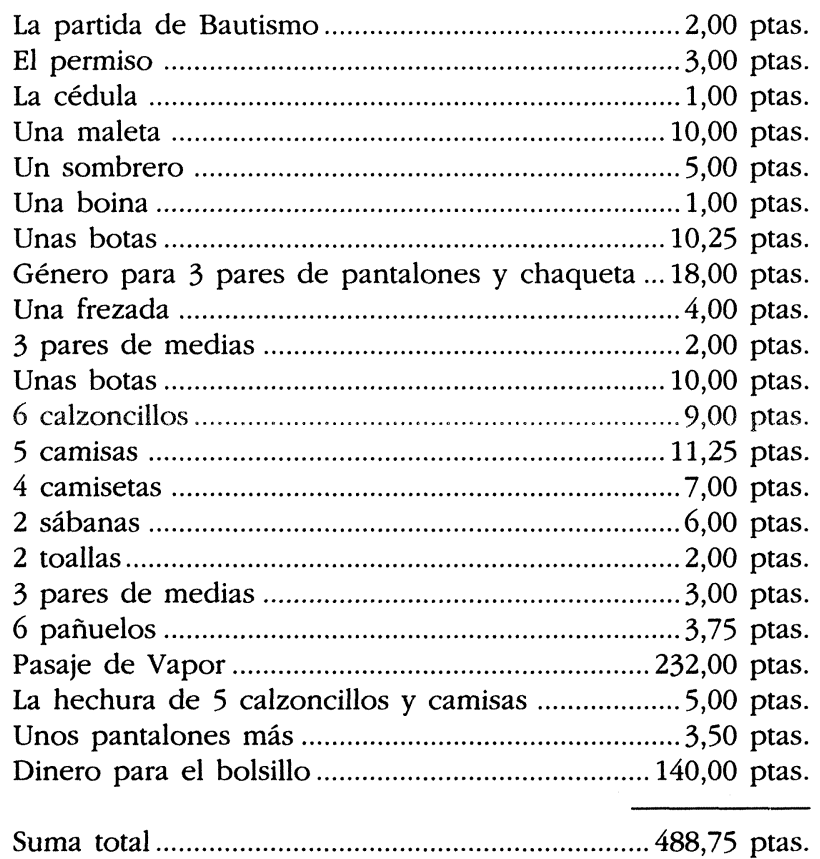

Gastos de pasaje de Secundino Suárez 2 de septiembre de 1921

Documentos del Ayuntamiento ...................................3,00 ptas.

La cartera carné ……................................................. 1,00 ptas.

Fotografía ................................................................. 7,00 ptas.

Cédula …................................................................. 1,00 ptas.

Juzgado de primera Instancia ...................................... 3,00 ptas.

Juzgado de $\mathrm{Paz}$........................................................ 7,00 ptas.

Guardia Civil ......................................................... 0,50 ptas.

Para el bolsillo 20 dóllares

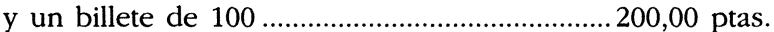

Pasaje de vapor, impuestos y automóvil

á Coruña .......................................................687,00 ptas.

Ropa y calzado y demás .......................................... 192,00 ptas.

El sastre la hechura ........................................... 21,00 ptas.

Suma total ....................................................... 1.123,15 ptas. 
Los hijos varones de la familia González emigraron a América con edades comprendidas entre los 13 y los 18 años. Sus puertos de salida fueron La Coruña, Vigo, Gijón y Santander. Nunca fueron solos en el viaje; unas veces iban dos hermanos juntos o acompañados por algún familiar y otras marchaban con conocidos, bien mozos como ellos, bien emigrantes de regreso a América que eran del mismo concejo de Valdés.

En 1899, emigraron los dos hermanos mayores de la familia González, José, de 15 años y Ramón, de 13 años. El primero cuenta las peripecias de su viaje en una carta escrita en Buenos Aires el 19 de noviembre de 1950 , y dirigida a su hermana más pequeña ${ }^{4}$ :

Creo haberte dicho en una de mis primeras cartas que el abuelo nos acompañó hasta la Coruña, y recuerdo haber prometido contarte algunas de sus ocurrencias. El primer día de viaje llegamos con la ferrocarrilana a Vega de Ribadeo. Ahí teníamos que atravesar un río muy ancho, en lancha, para llegar a Ribadeo, donde nos esperaba la otra combinación. Traíamos cada uno un baúl de esos tan clásicos, de lata, lleno de ropa. Un ajuar preparado por mamá para sus primeros hijos que se iban por el mundo. Estaban llenos y pesaban mucho. Para llegar a Ribadeo teníamos que subir una cuesta muy pendiente y por un camino malo. El pobre abuelo nos cargó el baúl sobre las costillas. Yo caminé unos pasos y lo tiré, le dije que era muy pesado y que no podía subirlo. Ramón hizo lo mismo. Primero se enfadó un poco y después les pagó unas pesetas a unos hombres que se ocupaban de esas cosas, para que los subieran hasta Ribadeo. Pero no quedó muy conforme. En la Coruña nos llevó a una fondita bastante ruin, pero cobraba poco y eso era lo más interesante. Él dormía en un cuarto. Ramón y yo en otro, dividido sólo por un tabique de madera. Cenábamos y a la cama. Calculábamos cuando podía estar dormido, nos levantábamos despacio, sin prender la luz y sin poner los zapatos para no despertarlo y salíamos. Recuerdo que una o dos veces fuimos a un circo, el primero que habíamos visto en la vida. Otras noches caminábamos por las calles, resplandecientes de luz, mirábamos los escaparates de las tiendas y las joyerías de la calle de "La Marina" y "Cantón Grande". Nunca nos dijo una sola palabra y nosotros, pobres tontos, nos creíamos que lo estabamos fastidiando al abuelo. Pero cuando volvió al pueblo de vuelta, le contó a mamá y a papá todo lo que hicimos. La primera carta que llegó venía llena de quejas, de reproches, por aquellos actos de insubordinación, sobre todo para mí, que era el más viejo (siempre la misma letanía) y debía de dar el ejemplo. Eran cartas bravísimas, llenas de lamentaciones y llegaban en los momentos más difíciles. Precisamente cuando más necesitaba una palabra de cariño, de consuelo, una palabra de esperanza, algo que infundiera ánimo, diciéndome que esos tiempos terribles no podían durar, que pronto habría de cambiar todo. [...]

4 Esta carta forma parte de la correspondencia que mantuvieron en los años cincuenta José González, nacido en 1882 y residente en Argentina desde 1899, y su hermana María, nacida en 1904 y vecina de Valdés. Ellos no llegaron a conocerse nunca personalmente. En estas cartas el hermano mayor rememora para su hermana toda su vida de emigrante en América. 
El abuelo nos embarcó en un vapor francés "El Corduan". Era lo más malo y lo más atorrante que Dios largó al mundo. Sigo creyendo que un individuo que hubiese cometido media docena de crímenes, el mejor castigo era mandarlo en ese vapor a la Argentina. Una sola noche tratamos de dormir en aquellas cuchetas asquerosas, resultaba imposible por el olor pestilente a orines y caca; no se podía respirar. Dormíamos arriba (35 días seguidos) encima de las lonas que tapaban las bodegas de carga. Las colchonetas estaban rellenas de paja, no había ni sábanas ni fundas, y la que me tocó a mí estaba manchada con sangre seca. La comida eran patatas sin pelar a mediodía, y por la noche un caldero de lentejas, que servían para cada 25 pasajeros. Lo que Carmen le dava a los gochos en nuestra casa era bastante mejor, resultaba casi un manjar. En todo el viaje no provamos nada de aquella porquería. Teníamos unas pesetas y comprávamos pan en la cantina, hasta que llegamos a las costas del Brasil. Allí compramos frutas, tarros de dulce y miel, y así alcanzamos a llegar a Buenos Aires.

En octubre de 1913 marcharon para Cuba los hermanos Pedro y Manuel, con 16 y 14 años de edad, acompañados de su hermana Elena y su cuñado y primo Antonio. A este último su suegro le había entregado 950 ptas. para correr con los gastos de los dos muchachos. El viaje lo hicieron en coche hasta San Esteban de Pravia, aquí cogieron el tren para Oviedo donde pasaron una noche en el Hotel Francés; de Oviedo a Gijón también fueron por ferrocarril. En este puerto se alojaron en el Hotel La Castellana (c. Corrida, 36), se hicieron unos retratos en el estudio del fotógrafo Julio Peinado (c. Corrida, 41 y 43), y compraron dos sillas de viaje y varios efectos en Casa Rato (c. Corrida, 39, 41 y 43) ${ }^{5}$ : "chocolate, galletas y etc.", así como manzanas. El pasaje les costo 241,60 ptas. a cada uno y era de tercera clase. El matrimonio, en cambio, fue en una clase superior. Al cabo de diecisiete días llegaron a La Habana, donde permanecieron varios días visitando a parientes y conociendo la ciudad. Su destino último era Rodas (provincia de Las Villas), cerca de Cienfuegos. Los tres hermanos mandaron a su llegada sus impresiones del viaje. Para los tres el mareo fue el mayor inconveniente.

Manuel, con 14 años, escribe desde La Habana, el 25 de octubre de 1913, una larga carta que ocupa cinco cuartillas $(215 \times 140 \mathrm{~mm}$.) por ambas caras con membrete del Hotel Alcázar (c. Prado, 121):

Querido hermano: Voy á darte alguno de los tramites que pasé y he visto pasar desde el siete de Octubre hasta ayer 24 del mismo. El día que embarcamos en Gijón metieron a bordo alcordeones, violinos, flautas, en fin, toda clase de músicas, contando no se marear y pasar la trabesía contentos. Salimos de Gijón y estu-

5 Las direcciones de las casas mencionadas proceden de Carnet-Guía de Gijón: Dedicado á los viajeros entre los Puertos de América y Gijón editado por el Comercio y la Industria y patrocinado por la Delegación del Centro Asturiano de la Habana, Gijón, s. a. [1915]. 
vimos hasta deshora de la noche divertidos, luego se bajaron al camarote á descansar las pocas horas que faltavan para amanecer. Cuando despertaron el barco estaba parado, así que no les dio tiempo á marearse, bueno al día siguiente lo mismo ¡Ay! que salimos de Vigo, y que no buelve a parar el barco, y que se empieza a perder la tierra, jajajay!, no se contaban cuatro horas cuando ya arriba [en] cubierta, en el piso de más abajo y en los descansos de las escaleras había más de media cuarta de bomitadas, yo todavía no había bomitado ¿Pero quién es capaz de aguantarse? Solamente de ver es incapaz el estomago de los cochinos de resistir aquello. Al día siguiente, de cuatrocientos solamente 1 se levantó, era un muchacho llamado un tal Canalejas, al cual todos quejábamos nuestros males; pero él aunque le dábamos propinas no nos quería obedecer porque decía que tenía bastante para él. Al día siguiente los males crecían, la mar se agitaba y se formaban unas montañas de agua que parecía sumerjir el barco, llegaban, daban una estampida lo mismo que si fuese una bomba enorme, el barco daba un balanceo, y en cada uno de esos se podían calcular que 20 hacían guaa, volvía otro y hacían 40 guaa, ¡Ay mi madri!, me despedí con intención de volverte á ver y fue para siempre, por aquí y por allá no se oían más que de estas jaculatorias. Otro decía: ¡Ay! si ahora me hallase en Vigo, pierdo todo el dinero y me quedo ¿Y que ivas hacer en Vigo? ¿Si te llevaban á la Guerra? Lo mismo me daba, allí siquiera moría a sangre caliente, que aquí muero á sangre fría y sin sentido. Y otro decía: jamás, jamás, si me dejas con un poco de vida jamás me volverás á coger. Y yo al oír estas oraciones encima de lo mío me hacía llorar, aunque yo no devía llorar; es decir llorar sí, pero no por ese concepto, llorar porque seré incapaz de pagar las obligaciones devidas á mis queridos papás, pero he de ir haciendo medios poco a poco para siquiera no darles disgustos é ir haciéndoles por la salud ¡Y con qué tranquilidad pasé yo catorce años sin saber las obligaciones que devía! Sali de Valdés, llegué á Oviedo, luego á Gijón, tampoco lo sabía, yo ya decía que el correr Mundo era buen negocio, pero parece que al embarcar iva mirando para el barco que me parecía bien y pegué un tropezón que me hizo gran efecto, se me abrieron los sentidos de tal manera que fue cuando empecé a ver los intereses que devía, principiándolos a ver por unos muchachos de diez y de doce años solos, sin recursos para valerse ¡cuanto mal pasarían! con ser yo, sin faltarme que comer ni faltarme nada, me cagué 30.000 veces en la vida, luego me calmaba un poco y pensaba ¿pero por qué me quejo? si estos pobres muchachos sin recursos están más tranquilos que yo. [...]

Pedro, el otro hermano que viaja con Manuel en 1913, no es tan aficionado a la escritura como este y escribe a su padre una carta muy breve, solamente una cuartilla del mismo Hotel Alcázar:

Querido papá: Hemos llegado ayer día 24 sin ninguna novedad. El viaje de vapor fue bastante bueno. Los primeros días nos mareamos algo porque estaba la mar un poco alborotada. La gente estaba intranquila hasta que no se mejoró un poco, pero ya luego nadie tenía ganas de salir: todos los días teníamos música, baile y rosario: estábamos como queríamos ${ }^{6}$. La que vino casi todo el camino

6 No era extraño que la música y el baile acompañasen a los pasajeros de tercera clase, pues el viaje era largo y sus condiciones bastante penosas. El entretenimien- 
mareada fue Elena [...]. Llegamos a las cuatro de mañana al Morro y tuvo que esperar a que amaneciera para entrar en el puerto, y ya estaban allí los negros con los botes para llevar la gente a Triscornia. Yo estaba asustado porque me dijera Elena un día antes que aunque fuéramos que no nos diera más que ya nos irían a buscar pronto, que no sabía si podríamos desembarcar cuando ellos; pero vino tío Ramón y Ángel de Cristino y dijeron que Manolo y yo teníamos carta presentada y además teníamos dinero bastante, porque muchos iban á presentarse y decían: qué dinero trae usted, diez pesos, a ver, sacaba un puñado de perras y algún duro, le decían: bueno, a Triscornia. Y otro le preguntaban y decía que los tenía en la maleta: a Triscornia. Así es que casi toda [la gente] fue [para Triscornia], salían unos vapores casi-tan grandes como el que nos trajo cargados para allá ${ }^{7}$.

Ayer nos vinieron a ver Jacinto el hijo del Sacristán, Jacinto de Cristino y un hijo de Florento el Pontigón. A mí no me gusta la Habana á pesar de estar en lo mejor de ella. Los negros me meten miedo, cada vez que veo uno pienso que me van a pegar. [...].

Elena, la hermana de Manuel y Pedro, fue la que hizo en 1913 una travesía en barco más penosa. Pasó muchos días mareada y encerrada en su camarote. Ella viajaba con su marido en primera clase a tenor de lo que cuenta, y no era para menos, pues este viaje no dejaba de ser su luna de miel. Después de los días malos escribe en el mismo barco que la lleva a Cuba:

El día que pude peinarme arranqué la mayor parte del pelo, tenía las manos como la Pucha q. e. p. d., las uñas largas y toda yo sucia como el sargento Miguel: los nenos [es decir, sus hermanos Pedro y Manuel] no se mudaron desde que salieron de casa, y yo nada les digo porque predicar sin ejemplo...

No achaquéis estos males a nada, son inevitables mareándose como yo: en nuestra mesa tenemos carnes de ternera, cerdo, cordero, pichón, pavo, conejo,

to hacía la travesía más llevadera y por ello no eran pocos los que en su equipaje incluían un instrumento musical. Elena González en una carta escrita en Las Palmas el 22 de enero de 1922, rumbo a La Habana, escribe: "los otros [conocidos] iban mirando el baile de muñeira que armaron abajo". Asimismo, el 26 de marzo de 1926 un emigrante de Llanes, que va en segunda clase, escribe a bordo del vapor Alfonso XIII: "Voy muy bien con los rapaces de la Borbolla pues son muy divertidos. De vez en cuando armamos cada alboroto cantando que la gente corre asustada.

Hoy es Domingo de Ramos y tuvimos misa a bordo bastante larga pero sin bendición de ramos. Lo pasamos muy bien con los de $3 .^{\mathrm{a}}$, son muy alegres. Cantan y bailan muy a menudo. Llevan gaita".

7 El campamento de Triscornia fue construido en 1900 para acoger a los emigrantes enfermos y a los que no tuvieran dinero, trabajo, persona o institución que respondiera por ellos. Permanecían allí hasta que no los reclamase algún familiar, amigo o centro regional. Sobre Triscornia y los trámites legales para entrar en Cuba en el primer tercio del siglo xx, véase Naranjo Orovio (1988: 83-92). 
etc. sopas muy variadas, pescados, frutas en conserva y naturales, dulces hechos á bordo diariamente y de conserva, guisos muy diferentes, buenos vinos, pan tierno, buenas galletas, etc. No puede pedirse más, y a pesar de eso mi alimento hasta hace dos y tres días ha consistido en té, café, leche esterilizada y caldo.

En 1919 marchó para la Argentina Ángel González; tenía 16 años recién cumplidos y su viaje fue un cúmulo de contratiempos. Salió de Santander el 27 de septiembre en el vapor Santa Isabel, hizo transbordo para el Reina Victoria en Cádiz, el 3 de octubre, y desembarcó en Buenos Aires el día 29 de ese mes. En la primera carta enviada a su madre desde Argentina le cuenta las peripecias de su travesía:

El día 27 salimos de Santander. El mar estaba un poco malo, nos mareamos algo, no fue nada. Llegamos a la Coruña el día 28 por la tarde, salimos el mismo día. Llegamos a Villagarcía a las ocho de la mañana y salimos a las doce para Vigo, yo ya sentía el hambre, llegamos a las 4 de la tarde, salimos a tierra, yo comí como un lovo; por la noche nos fuimos al vapor; por la mañana volvimos a tierra, comimos bien y otra vez al vapor. Yo me compré unas latas de sardinas que valía más que Dios en aquel momento me dejase sin dinero.

Salimos para Cádiz el día treinta. El día treinta y uno por la tarde yo me comí las sardinas y por la noche ya no podía moverme, sentáronme en una silla, me dieron mil cosas que enseguida las devolvía, me dieron una purga y me hizo vastante bien. Yo decía que daba la vuelta de Cádiz y gracias a los compañeros que me quitaron las intenciones. Llegamos a Cádiz el día 1 a las 6 de la tarde, hasta el otro día por la mañana no podimos saltar a tierra.

Ahora no se disguste que viene lo más gordo. [...]

Lo "más gordo" fue que su baúl no lo pudo facturar en Santander por llegar tarde, y durante el transbordo en Cádiz se perdió. Fue a reclamar a los marineros y le "dijeron que ya era tarde que mañana se arreglaría eso".

Al otro día nos mandan que vayamos a estar con el contramaestre y nos pidió el talón [de la facturación], dije que no tenía y como éramos muchachos y no teníamos talón no hizo caso de nosotros. Cuando vino Don Cándido yo le dije lo que pasaba y dijo que diese una pts. al vodeguero para ver si estaba allí, vaya un consuelo de tripas.

Salimos de Cádiz a las 6 de la tarde de el día 4, a una tormenta que aquello metía miedo. Los marineros al pasar el estrecho de Gibraltar ya daban el vapor perdido. Los escapularios no los tiré por que no podía, pero sí ofrecí a las ánimas una misa y al manco de la Carril una pts., la misa dará Ud. ahí que cuando pueda se la mandaré.

El día 7 llegamos a Canarias, ya no tenía miedo, salimos el mismo día. [...]. Siguiendo mi viaje, después que salimos de Canarias, unos 4, me puse malo que aquello era terrible, me pasé 6 días sin tomar otra cosa que refrescos [que] me traían los de Villar, lo que es a los sobrinos de Dn. Cándido bien poco tengo que agradecer [...]. 
A los de Villar les darás las gracias a los padres, el hijo de Juaco de la Pega no se separaba de mí ni un momento, me quería como un hermano, me traía cuanto necesitaba, el otro tenía vastante para él. Un día salimos del camarote y subiendo las escaleras la vista se me iba, ya no podía ver nada, me caí. Vino un médico, me preguntó qué tenía, yo le dije: mucho calor y algo mareado, me dijo: anda sube arriba a tomar el fresco. Me levanté, me fui como pude y mandé al de Villar que fuese a vuscarme una purga. Va él y cuenta todo al médico, sin saber nada le manda que vaya yo a tomarla y que me llevase a la enfermería. No fui. Al poco tiempo vino a vuscarme y me escondí y me fui a proa, cuando él estaba en proa me fui a popa y no me pudo cojer. Aquel día metieron [a] 80 en la enfermería, pero era al pasar el Ecuador y fue por el mucho calor. Muerte hubo, pero como quien dice ninguna, una mujer de un mal parto y uno tuberculoso. No hagáis caso de los periódicos. El 16 yo ya no tenía nada, estaba bueno. Llegamos a Montevideo el día 22 y a Buenos Aires el 23. Estuvimos en la rada hasta el 29 [...]. Las cartas a tierra no las querían llevar porque decían que tenían gripe. Llevaron 7 enfermos a la isla. [...].

En el puerto esperaban a Ángel sus hermanos Francisco y José. Con Francisco y su mujer se iría para Aguas Buenas, una población nueva levantada sobre el Ferrocarril del Oeste, a trabajar en el comercio de éste.

El último hermano de la familia González que marchó para América fue Jacinto. Acompañado por su primo y cuñado Antonio llegó a La Habana en 1920. El 4 de mayo escribe a su madre desde Estación Balbín (Rodas) dándole cuenta del viaje. A través de esta carta conoceremos el estado de ánimo de la madre cada vez que marchaba un hijo, sobre todo estos últimos; las personas que visitan al llegar, todos parientes y vecinos de Valdés, y que constituirán el ámbito de sus relaciones; la descripción del estado en que se encuentran sus hermanos Pedro y Manuel que llevan siete años en Cuba, y la primera impresión que le causa la ciudad de La Habana.

Mi querida mamá: Hoy a las 8 de la mañana llegamos sin novedad a ésta después de 22 días de viaje y gozamos de completa salud gracias a Dios.

Me figuro que Ud. se pasaría todos los días llorando como hacía con Ángel hasta no recibir noticias de nuestra feliz llegada, mientras nosotros nos distraíamos lo mejor que podíamos en el vapor. No debe Ud. preocuparse por nosotros porque estamos bien y muy contentos. Pedro es lo mismo que siempre y Manolo muy alto pero los dos de un color sano y fuertes. [...]

Las peripecias de nuestro viaje se las cuento a Joaquín. La Habana me ha gustado pero no me ha deslumbrado como a otros. Tiene de todo, bueno y malo. Allí he visto a Emilio, a Manuel del Sacristán, Felipe Lombán que está muy crecido y a Eduardo; a Eduardito no lo he visto. Emilio y Manuel del Sacristán me parecieron bastante desmejorados; los otros están buenos.

Tío Ramón se me pareció a buelo Q. E. D. Está viejo ya y Nieves muy enferma. [...]. Etelvino está grueso; de lo demás es como siempre. El calor no es tanto como la gente lo pinta; hasta ahora no he necesitado el purgarme. 
Balbín me gusta para estar en él más que la Habana. En todo el tiempo que he estado allí no dejé de temblar, temiendo que algún automóvil o tranvía me matase; allí tiene uno la vida en constante peligro y aquí se está más tranquilo. Un día he de hacerles un dibujo de la tienda para que vean cómo es.

Me parece que en un sueño he pasado de España a Cuba. Aún no me he dado perfecta cuenta que estoy aquí. Continuamente están llegando guagiros a saludar a Antonio, a mí me gusta esta gente. [...]. De las primas y tíos sólo te diré que han estado muy atentos con nosotros. [...].

Las dos cartas siguientes son muy diferentes a las que hemos visto hasta ahora. No son las cartas de un joven emigrante recién llegado, sino las de un emigrante adulto que acaba de retornar a La Habana después de una estancia en Valdés. Escribe a su amigo Joaquín González, que por aquellas fechas tramitaba la venta de pasajes para una agencia de La Coruña, y en sus cartas aparecen muchos de los usos y de las vicisitudes que caracterizan el viaje del emigrante: lleva diversos encargos para otros emigrantes y acompaña a varios mozos, algunos de los cuales marchan ilegalmente, siendo ésta la razón de que embarquen en el puerto de Vigo, que era uno de los más recomendados para efectuar la salida de emigrantes clandestinos. El autor de estas cartas tiene un pequeño capital y quiere comprar una "bodega" (comercio) en La Habana. El ambiente que se encuentra no es bueno para comenzar un negocio, pero él, que ya pasó por dependiente, no quiere volver a ese estado. Está dispuesto a volver para Asturias si no encuentra algo de su gusto.

Habana, 26 de junio de 1921

Joaquín González:

Mi querido, en este momento recibí su tan estimada carta con fecha 25 de Mayo. Enterado de ella beo que siguen todos buenos de saluz, eso para mí es un placer más grande que yo podiera recibir, quedando nosotros en ygual estado de saluz. Pues bien ya yo le [he] escrito desde Vigo manifestándole todas las cosas, pero por lo que ya beo no llegó a sus manos.

Pero yo después que llegué le escribí, en ygual condiciones ya beo que también Dn. Juan le escribió. Pues bien, los gastos de embarque son los siguientes: el viaje mío 400 pesetas más 100 pts. de papeles; los niños 206 pesetas por cabeza, por separado 187 pesetas, mas por los papeles de los niños no estoy seguro pero creo que fueron 300 pts., tengo el apunte guardado pero ya yo en la anterior se lo dije; y el de Paulino 400 y más 125 pesetas por la falta de la firma de la licencia que parece ha sido un descuido. Yo te soy franco no tengo queja alguna de esa familia por el motibo que nosotros éramos lo mismo que de casa, y el hombre la verdaz que está bien pagado porque lo que ace no son todos los que lo pueden acer. Tu bien sabes que si no se unta el carro no camina, por lo tanto el estar fuera de la ley tiene que pagarse, así que por lo demás ya tú sabes que él dice que si no embarcan por la escalera que los embarca por la chimenea y él lo dice y lo ace, así que por lo tanto puedes estarte tranquilo. 
Joaquín, el encargo de tu cuñado yo no pude ir a llebárselo por el motibo de los niños, que tú bien sabes que no se pueden abandonarlos. Yo le escribí para ber en qué forma se lo mandaba, y entonces me contestó y me dijo que lo llebase Amargura que es un almacén y que él tenía negocios con ellos y tenían facilidaz de poder mandarlo. Yo le yce según él me dijo y con la misma le escribí diciéndoselo y no me contestó. Son éstas las oras que no sé palabra, yo les boy escribir otra para saber si recibieron el encargo o no.

Joaquín, esto esta bastante mal. No creas otra cosa. Los Bancos y Cajas de Ahorros todos están cerrados y yo creo que no cobre ni un rial de todos esos capitales. Los establecimientos piden por ellos lo [que] no balen. Yo según beo las cosas creo que pronto estaré a tu lado. Paulino está trabajando desde que llegó y los dos niños mayores también, pero yo para trabajar ganando un sueldo no quiero y para comprar no es posible, porque piden lo que no balen. [...]

Habana 6 de Noviembre de 1921

Joaquín González:

Muy Sr. Mío, quiera Dios que cuando ésta llegue a sus manos se encuentren todos buenos, por esta su casa todos bien.

Referente al viaje, muy bien, nada más que tardó 15 días, por lo demás muy bien en el trato y comidas, todo estaba bueno.

Referente a la caja de los encargos todo llegó bien, pero muy costoso, sólo en la aduana me cobraron 22 pesos, y considera [que] nadie [me] pagó nada, así que los encargos me cuestan mas de 40 pesos y para no ser agradecido. Las muchachas gracias a que yo me planté que si no sabe Dios lo que sería de alguna de ellas, así que te garantizo que si algún biaje más doy, de nadie más me hago cargo. La de Barcia fue a Triscornia y la saqué al otro día y estubo en casa de mi hermano hasta que se colocó en el Bedado. Referente a tu encargo de la patata pues se pudrió y yo no pude ir a ber a tu primo por el motibo que al segundo día de la llegada pues apareció esta casa que reúne buenas condiciones para mí y compré en 3.700 pesos bodega y casa amueblada y todo que está en San Pablo y Martí en la Ceiba, así que ya sabes tu casa para lo que les puedamos serbir. La casa por ahora estamos muy contentos con ella.

Del encargo de tu hermana ya lo recibió. Todos están buenos, así que deseo me perdones por no aber ydo ber tu pariente pues estoy trabajando la casa con José Ramón y él no está al tanto de el despacho y ése es el motibo que yo no puedo salir de casa, así que el día que le escribas a él se lo dices y el día que benga a la Habana le das las señas para que pase por aquí. [...]

\section{EL TRABAJO Y LOS NEGOCIOS}

Los emigrantes asturianos iban normalmente con un trabajo buscado de antemano. Unas veces acababan en el comercio de un tío, un hermano o un vecino, otras los estaban esperando estos mismos para llevarlos a trabajar con un conocido y otras llevaban cartas de recomendación que 
facilitaban su colocación. La mayoría de los emigrantes trabajaban en comercios y comenzaban su carrera como aprendices y dependientes, llegando después de años de ahorro y esfuerzo a montar un comercio por su cuenta. La vida laboral de los hermanos González constituye un buen ejemplo de la biografía de muchos emigrantes asturianos.

Los primeros hijos de la familia marcharon para la Argentina en 1899, y no a Cuba como hubiese sido lo natural, pues allí tenían familia, allí había estado su padre y allí mantenía todavía éste unos intereses. La razón de no ir a Cuba está en las noticias que por carta recibe su padre de un tío político suyo, Fernando Menéndez (1840-1901), que vivía en La Habana. El padre, buscando el mejor destino para su hijos, solicitó a su pariente noticias sobre la situación en la Isla de Cuba. El 19 de julio de 1899, Menéndez le escribe que en esos días "es una imprudencia el salir de La Habana, y viendo como están las cosas con los españoles, que no tenemos seguridad ninguna porque lo matan a uno como si fuese un perro, quedando todo impugne.. Pero sus impresiones no se reducen solo a estas palabras:

Con respecto a la situación del país a que se refiere en su $2 .^{\circ}$ párrafo [de la carta del padre de la familia González], es muy abenturado formar ningún juicio el decirle

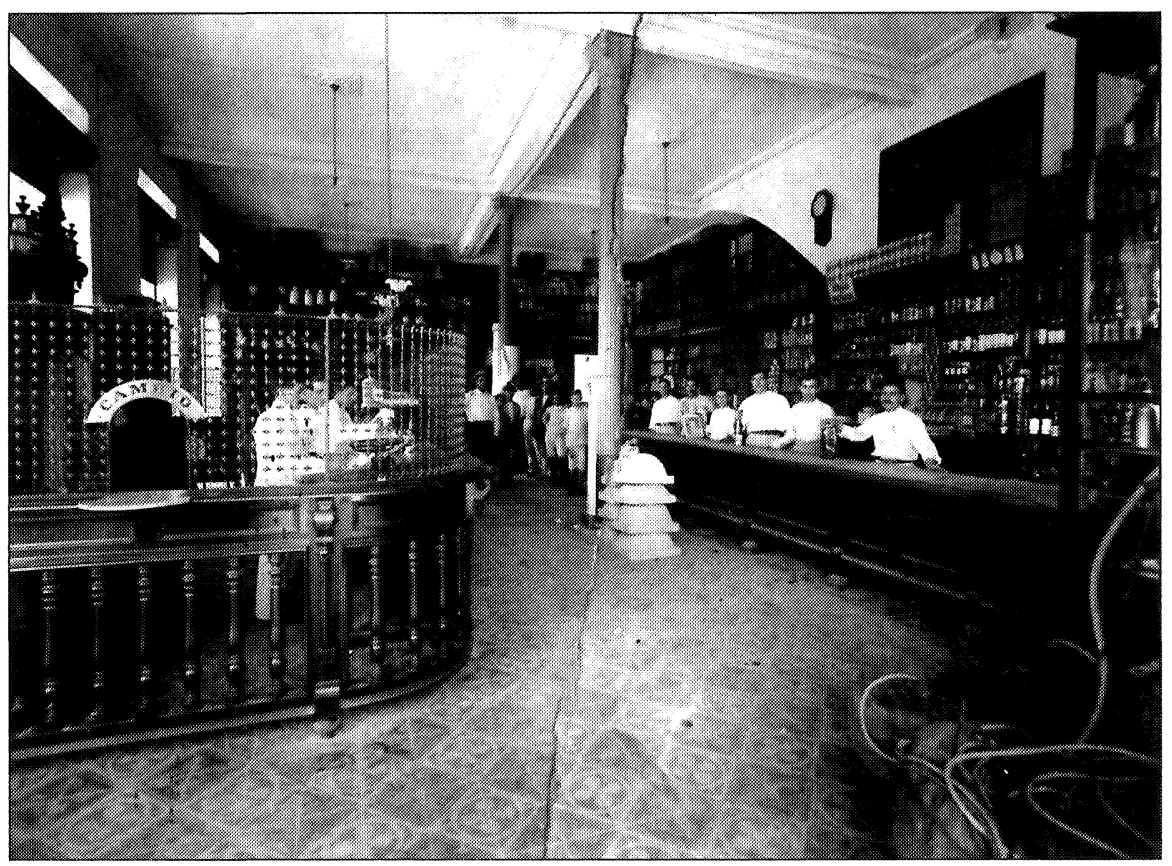

FIgura 2.-Anónimo, Comercio de emigrantes de Piloña (Asturias) en Cuba, h. 1905. Manuscrito en el reverso: En prueba del cariño / que te profesa, te dedica este / recuerdo tu hermano / Armando. Col. Museo del Pueblo de Asturias. 
que esto está muy mal, esto lo sabe U. y lo sabemos todos, como seguridad personal, es tal el odio a los españoles que no se puede salir de la Habana, sobre todo la Vuelta Arriba, en la Vuelta Abajo dan mas prueba de sensatez con la unión de los peninsulares y se trabaja. Las partidas de allá arriba todos son negros, estos están en su Cuba livre y muy embalentonados, como ellos dicen que para eso lo han ganado. Todos los días estamos biendo robos y macheteados peninsulares, la prensa española se queja amargamente de estos escándalos, y el gobierno interbentor oye esto como el que oye llover, nada les importa que aya crímenes ni escándalos ellos ban con negocio. Pobres de nosotros si esto llegase a ser independiente, pues estoy seguro que no tardaría ni dos meses en ser de los negros, y con el odio de raza figúrese, estoy seguro que aquí no quedaría ni un español, pero ni hijo de aquí, que teniendo para el pasaje no abandonase esto. Lo dicen todas las personas sensatas, mientras que la chusma y la prensa sucia no se les puede aguantar las desvergüenzas que le sueltan a uno en la cara. Esto es vivir peor que en el infierno, si es que lo hay; cunde la desconfianza paralizando todo y si no se puede travajar en el campo que es donde tiene que salir la riqueza del país, estamos de más, apaga y bamonos. Esta es hoy la situación de este tan desgraciado país devido a nuestros tan pícaros como ladrones gobiernos.

Con estas noticias es comprensible que en septiembre de 1899 el padre de los hermanos González enviase a sus hijos a la Argentina. Los dos se colocaron de empleados. José trabajó los primeros años en la casa Fernández Roca C. ${ }^{a}$ de Rosario (propiedad de un gallego de Ribadeo y un catalán de Vilanova y Geltrú), adonde llegó recomendado por don Ramón Asenjo, emigrante natural de Luarca, enriquecido en Argentina y amigo del padre. Así recordaba él mismo su trabajo en esos primeros años, en una carta escrita a una hermana el 10 de marzo de $1953^{8}$ :

Creo recordar que llegamos a la Argentina a fines del año 1899. Así que el primer Carnaval que me tocó ver fue el de 1900. Era uno de los últimos cadetes en lo de Fernández Roca Cía. de Rosario. La casa estaba en la calle Córdoba, la más importante y la más aristocrática de la ciudad [...]. Tenía varias entradas con ventanales o balcones, que davan frente a la calle Córdoba. Durante los días de Carnaval, en ese sitio, improvisavan varios palcos para las familias de los socios y una cantidad de invitados, todos de su relación. Desde allí presenciavan el desfile y jugavan con flores y serpentinas. Mientras tanto, la muchachada, aquella colección de pequeños esclavos, seguíamos con nuestro trabajo, que no se terminaba nunca. Separábamos las mercaderías vendidas durante el día y los pedidos de los viajantes. Después las llevávamos al empaque y una vez que se había terminado de encajonar eran la una o las dos de la madrugada. Como los desfoyones, con la diferencia que aquello duraba todo el año, desde el $1 .^{\circ}$ de Enero al 31 de Diciembre. ¿Quién pensaba en hacer la cama? Tirávamos el colchón encima de algún mostrador, o para hacer más pronto, sobre las banquetas del empaque. Mucho mejor, total el catre estaba lleno de chinches. Era tan grande el cansancio

\footnotetext{
8 Véase nota 4.
} 
que muchas veces quedava dormido sin desnudarme, con los pantalones o con un zapato sin sacar. [...] Pero sigamos con nuestro tema, cuando tenía que subir al cuarto o quinto estante a buscar camisetas, medias, pañuelos o sombreros, desde la escalera alcanzaba a ver el corso, el desfile de coches y carros adornados con sumo gusto, el ruido, la alegría de aquella multitud. En verdad parecía un capítulo de las "mil y una noches". Y quedava como clavado en la escalera, contemplando aquel espectáculo, nunca visto ni soñado. Hasta que sentía el grito de alguno de los jefes: —ieh, qué está haciendo ahí, se ha quedado dormido? - iy entonces se acabó la fiesta! Pasaron algunos años y también yo fui a muchos corsos, en distintas ciudades de la República y me tocó jugar con flores, con serpentinas, con pomos, con papel picado, etc. Pero ya no eran tan lindos como los primeros, cuando no podía ir y los miraba desde la escalera.

Pocos años después, José pasó a trabajar en un comercio de Buenos Aires, con la oposición del padre, y durante muchos años fue viajante de esta casa.

También marchó para la Argentina el tercer hermano varón de la familia González, Francisco, que trabajó entre 1904 y 1911 como empleado de comercio en varias poblaciones situadas sobre la línea de Ferrocarril del Oeste (Melincué, González Moreno, Meridiano 5o). En ese último año, con 23 años de edad, se estableció por su cuenta con otro socio en Mariano Miró (provincia de Buenos Aires), fundando la sociedad "Armesto, González y Cía. Sucesores de Fernández Figar, Reinoso y Cía.". Desde esa población escribe a su hermano Joaquín, el 10 de septiembre de 1911, una carta muy breve en la que le informa del nuevo rumbo que ha tomado su vida y le pide que tranquilice a su padre ante ese cambio:

Querido hermano: Quizás te extrañe la dirección de esta carta pero mi destino se hizo así y ahora será lo que Dios quiera.

He llegado donde quería y deseaba hace tiempo y creo [que], si la suerte me ayuda, para dentro de unos años ser algo. [...].

Nota: Decíle á papá que le mandaré copia del contrato cuando lo firme y que esté tranquilo que voy a ganar más que con Sequeiros.

Cinco meses más tarde, el 22 de febrero de 1912, Francisco envía a su casa en Valdés la prueba fehaciente de su nuevo estado laboral: la fotografía de su comercio, acompañada de una carta en la que identifica a las personas que aparecen en la imagen:

Querido hermano: Sin ninguna tuya á que referirme, la presente es para comunicarte que con esta fecha te remito una fotografía con una vista parcial de $\mathrm{mi}$ casa de comercio, para que tengas el agrado de conocerla aunque nada más sea en esa forma. El que va marcado con el número uno es mi socio Armesto, el dos es el gefe de la estación y el tres es el oficial de policía, los demás son los empleados de la casa. 
A fines de 1913, Francisco y su socio abren una sucursal en la estación de Aguas Buenas, que era una población nueva levantada junto al Ferrocarril del Oeste y situada a dos leguas de Mariano Miró. La presencia de emigrantes en la campiña argentina y la apertura de estos establecimientos comerciales fue la consecuencia de una transformación vigorosa del campo argentino, que supuso la expansión de tierra cultivada, el crecimiento de la producción de cereales, sobre todo de trigo, y el aumento de la población y el consumo. Los beneficios de estos comercios fluctuarán dependiendo de las cosechas de cereal; así lo cuenta Francisco en una carta escrita desde Aguas Buenas el 20 de noviembre de 1913 y dirigida a su hermano Joaquín:

Tengo muchas explicaciones que darte sobre lo que vos te refieres en la tuya referente a los trabajos y calamidades que hay que sufrir en estos países.

Hasta hace cosa de ocho días teníamos una cosecha nunca vista por estas zonas y hoy ya tenemos perdido un $30 \%$. Después de llevar dos años malísimos y no tener en estos puntos otra esperanza que la cosecha del trigo y verla de la noche a la mañana perderse ya podrás figurarte como quedará uno. Si no biene ningún otro contratiempo aun vamos á tener una cosecha regular, pero estamos tan asustados que tenemos todas nuestras esperanzas perdidas de que nos pueda ir bien. Por hoy no puedo darte más datos sobre la cosecha, pues todo lo que se diga son habladurías.

Pasando á la cuestión del negocio debo advertirte que no conoces la forma de trabajar de este país y por eso lo encuentras tan fácil todo cuanto dices en la tuya. Has de saber que aquí se fía todo el año la mercadería que se vende hasta que no se cosecha el trigo. Si hay trigo pagan todo lo que deben y si no tienen que volver á sembrar y nosotros los tenemos que mantener hasta la nueva cosecha otra vez. Como ya llevamos dos años sin cobrar nada de lo que hemos vendido y nosotros tenemos que pagar en Buenos Aires cada 6 meses, figúrate ahora cual será nuestra situación si no hay cosecha.

Esto, querido Joaquín, es más fácil decirlo que estar en ello y un año de estos dos que me tocaron a mí representa diez de trabajo en otra forma y por lo mismo no debe de extrañarte que me encuentre hoy abatido y desesperado por tanta calamidad.

Siete años más tarde la situación económica de este emigrante seguía siendo bastante precaria. En una carta escrita a su hermano Manuel, once años más joven que él y establecido en Cuba, le cuenta su situación:

Yo de este país hospitalario poco te puedo decir; tengo que ser muy esclavo de mi cuerpo para ver si puedo llegar algún día á descansar y desde la muerte de mi querido socio mucho más aún, pues ahora toda carga pesa sobre mí solo y es mucho.

Mi vida se desarrolla lo mismo que la de los animales: comer, dormir y trabajar, diversiones no hay, cada año o medio año que le hago una visita a José Inuestro 
hermanol quiero distraerme un poco pero enseguida los negocios reclaman mi presencia y hay que volver al yugo.

Yo pensaba este año ir a ver a Mamá, pero mis castillos se derrumbaron y no sé cuando podrá ser, a pesar que si Ángel es aplicado como hasta la fecha pienso dejarlo con otro muchacho muy bueno que tengo aquí y entonces aunque no sea más que 2 meses iré; pero para ello tendrán que pasar 2 ó 3 años aún. [...]

Espero me perdones el que no continúe, pero me es imposible debido a lo mucho que hay que trabajar y el tiempo no es el suficiente, pues los días son cortos y las noches muy frías (Aguas Buenas, 23 de julio de 1920).

Las penas de Francisco, emigrante al que nadie le regaló nada y que pasó por todos los estadios del comercio, desde dependiente a propietario, contrastan con las impresiones que del trabajo tiene su hermano Ángel, quince años más joven que aquél, y que llegó de Valdés al establecimiento de su hermano con todas las facilidades y con la protección familiar del mismo hermano y su cuñada.

Sin ninguna vuestra voy a escribirte dos letras para entretener el ansia que tengo de recibir noticias vuestras.

Estoy muy contento por que la América no es como dicen muchos que hay que trabajar. Lo que hay que hacer en ésta es el no ser un atorrante y tener un poco de voluntad al trabajo. A mi me vasta ver los dependientes que hay aquí, están protestando con la América, dicen que si tubiesen plata se marcharían a España. Yo ahí no trabajaba nada, pero menos que eso trabajo aquí (Aguas Buenas, 25 de enero de 1920).

Con una protección parecida llegan los hermanos Pedro y Manuel a Cuba en 1913; sin embargo aquí su primo y cuñado Antonio no tiene todavía un comercio y lo que hace es conseguirles trabajo en casas de conocidos. Manuel entra a trabajar en 1914 en el comercio "La Casa Grande", propiedad de Eusebio Lilí Larrinaga, en Manguito; tiene 14 años, lleva seis meses en Cuba y contesta inmediatamente a una carta de su hermano Joaquín. En esta epístola, escrita el 18 de marzo de 1914, cuenta su situación como dependiente en un comercio:

Queridísimo hermano:

Hace dos horas recibí tu carta y la de Carmina, las cuales me causaron inmensa alegría. Acabamos de cerrar [el comercio] y aunque estoy un poco cansado me pongo a contestaros para que coja el correo del 20 que es el más próximo y para que no tengáis que esperar mucho. Yo me porto lo mejor que puedo con todos, nos queremos como hermanos, malas compañías no las podemos tener aunque quiéramos, porque $1 \mathrm{vez}$ cada año que nos dejarán salir, la he de aprovechar para pasar 3 ó 4 días feliz con mis padres de Cuba [su hermana Elena y su primo y cuñado Antoniol y hermano. Desde el día en que salimos de casa debíamos de estar dando gracias al Señor por lo bien que nos va, todavía no se nos ha puesto 
nada por alante. Yo esperar, esperé, pero me tocó una casa de las mejores de Cuba, tubo que haber sido nuestro Señor quien ayudó a Antonio á buscarla. Desde el día en que salí de casa no he sabido lo que es tener hambre, y en la forma que está Cuba. Quisiera y me da pena contaros lo que hablan aquí los marchantes, lo hay que dice: ya mi familia está pasando hambre y yo no puedo más, pero el día que mis fuerzas no alcancen más, me meto á robar, yo no dejo morir ó no quiero ver á mis hijos y mujer morir de hambre, es muy triste eso, y por lo regular todos bienen con la misma. El amo nos dice, no quiero veros pasar hambre, pues quiero que trabajéis. Los huevos están a 30 por peso comprándolos al por mayor, y no se pasa día que no comamos 4 ó 6 cada uno, y eso nada más como un engrediente de la demás comida. Para decirte mejor, hace dos ó tres años comían en la fonda y dijo el amo que no se conformaba con la comida de la fonda, enseguida hizo cocina, trajo cocinero y á comer de lo mejor que hay para conservar buena la saluz.

Estoy perfectamente bien, no tengo nada que desear, únicamente el dinero, que eso para sacárselo hoy á Cuba se necesita tener cuernos en la frente. La saluz ya se sabe que se pierde donde quiera, pero los que bienen para esta casa, ó han benido, á ninguno se le ha conocido una enfermedad. Nos labamos todos los días 2 veces y nos peinamos, nos bañamos 2 veces á la semana y nos cambiamos toda la ropa, andamos figurines como ahí los días de fiesta 9. Mira si hace dinero la casa, tiene por tarifa 300 pesos diarios, no sé que tanto por ciento, y hoy fue un día que se hicieron 400 , lleban mucho fiado, pero no pierde gran cosa. [...]. Estáy descuidados con nosotros, mejor es imposible que nos baya.

Años después, Manuel y su hermano Pedro irán a trabajar en las proximidades de Rodas con su primo y cuñado Antonio. Este poseía varios comercios situados en zonas rurales, junto a estaciones de ferrocarril y centrales azucareras. El establecimiento en estos lugares fue una característica de la inmigración española en Cuba a partir de 1910, que cambió su norma de asentarse únicamente en las ciudades para dirigirse a nuevas áreas rurales en explotación y dedicarse no a labores agrícolas, sino

9 La costumbre de asearse a diario, adquirida por los emigrantes en América, fue generalizándose en Asturias a través de la influencia que estos ejercen sobre sus familias y vecinos. La noticia siguiente referida a la casa rural en el concejo de Castropol es un buen testimonio de esta influencia: "Casas donde bay un americano. Unas son nuevas y cómodas; otras son la renovación de la antigua casa paterna. Son limpias y con buenos servicios higiénicos. En Asturias, el elemento americano es civilizador en todo, incluso en la propaganda de las buenas ventajas de la higiene. Otras casas de americano tienen el cuarto. Se trata de familias pobres que esperan al hijo no muy rico y antes de que éste llegue de Cuba le hacen una habitación, adosada a la casa, blanqueada, tallada y amueblada modestamente; esto es el cuarto, que contemplan con admiración los vecinos pobres, y hacen bien, porque desde el cuarto y de su habitante han de salir provechosas enseñanzas de higiene personal, como son el uso del jabón y el aseo diario de la cara y el semanal de los pies, amén del frecuente cambio de ropa interior, entre otras cosas" (Álvarez Sierra 1946: 54). 
a la explotación de comercios o a tareas industriales en la producción de azúcar. Lógicamente, los comercios de nuestros emigrantes estarán a expensas de las alzas y bajas del negocio azucarero, del mismo modo que el resto de los sectores de la economía cubana ${ }^{10}$. La evolución económica de este país se observa bien en dos cartas escritas por Manuel González en 1919 y 1923. La primera coincide con el alza del precio del azúcar que trae consigo la Primera Guerra Mundial y la segunda coincide con el final de un periodo de recesión iniciado en $1920^{11}$. En ambas cartas el estado de ánimo que manifiesta el emigrante es un trasunto del estado económico por el que atraviesa la república cubana

La primera carta, fechada en Rodas el 9 de diciembre de 1919, va dirigida a su cuñado Antonio, propietario del comercio, que está en Valdés (Asturias). En ella hace balance del negocio desde su marcha.

Querido Antonio:

Nos es grato adjuntarte a la presente una letra por valor de quinientas pesetas, dejando con ello cumplimentados tus deseos según carta de fecha 7 del pasado noviembre.

Si necesitas más ya sabes donde hay, y no te de lástima decir aquello de, manden ... que estamos ganando. Nuestra potencialidad económica es indiscutible, la prueba es que te giramos antes de vencer el plazo puesto por ti para el efecto.

Hay en la actualidad mil y pico de pesos en los Bancos dispuestos para cubrir los vencimientos que se vayan presentando.

Tenemos bastante mercancía en la casa y un pedido en camino para la casa de Trápaga, por valor de mil y pico de pesos.

El central empezó a moler el día 7 y con él un movimiento beneficioso para todos. Por este motivo dejamos correrse a los clientes de crédito y hasta los asesoramos para que compren mucho, pues ya pronto se recuperará esto y lo atrasado. Te doy estos datos porque tengo la seguridad que tendrás tiempo de ver el balance de este mes antes de embarcar y quiero tenerte preparado para que no te asuste la cuenta de Varios. Pasará bastante de los tres mil. Vendemos a más de cien pesos por día y gran parte de esto al crédito. Ramón Fernández es también este año el contratista del piso de azúcar. Tiene a Salvador Parrondo de encargado de la cocina y excuso decirte el interés que se toma por hacernos el mayor gasto. Es además un escelente propagandista de la casa, y por su constancia y desinterés merece un premio. Para éste y algún otro parecido es para quien te mandaba traer algo de ésa como gratificación y recuerdo.

La casa de Antonio González, sirve para esta zona de sucursal de todas las casas importadoras o poseedoras de los artículos necesarios para la vida; si el marchante que pide o desea es de confianza (en el sentido monetario) no se le

10 Sobre el destino de los emigrantes en el primer tercio del siglo xx y el desarrollo azucarero, véase Le Riverend (1985: 566-588).

11 Sobre la crisis cubana iniciada en octubre de 1920 y sus consecuencias entre los emigrantes españoles, véase Naranjo Orovio (1988: 219-224). 
dice que no, no importa que el objeto apetecido pertenezca a los víveres, ferretería, ropa, quincalla, sedería, talabartería, peletería; química, fisica, astronomía, guerra, marina, aviación, ortopedia, etc., lo mismo se le consigue un avión que un braguero si lo desea, todo por una pequeña comisión. [...]

Cuatro años más tarde, en 1923, el optimismo que desprende esta carta será un oscuro recuerdo. Los malos años pasados en Cuba, tras la crisis de 1920, han logrado que Manuel manifieste en sus cartas el espíritu de un superviviente y no el de una persona que aspira a enriquecerse. Tiene 24 años, lleva diez en Cuba y en una carta a su hermano Joaquín hace el siguiente balance de su estancia allí:

La situación de este país cambia favorablemente de día en día, hoy reina un optimismo tan grande que talmente parece que volvemos a una era de prosperidad pocas veces igualada, claro está que hemos pasado días terribles, tristísimos, con presentimientos funestos, pero afortunadamente pasaron hace tiempo. [...]

Si después de pasar tantos trabajos como pasé en estos últimos años con mil privaciones y con un anhelo supremo, el de ir a ésa en verano, me hubiera muerto, mi muerte habría sido de lo más terriblemente triste para mí y para los que presenciaran mi muerte a los 22 ó 23 años sin haber gozado lo más mínimo de esta perra vida. Afortunadamente estoy vivo y sin excederme procuro vivir mejor. Tengo aspiraciones legítimas e ideales nobles, pero no me mato por hacerlos cristalizar, una perseverancia pasiva y el tiempo se encargarán de hacerlas llegar. Empiezo a divertirme con Cupido porque es paradójico e increíble que haya llegado a los 24 sin tener una novia; empiezo a aprender a bailar y ya frecuento los bailes de campo para ver y decir mis cositas [a las] muchachas. Voy cada vez que puedo al cine y a ver desafíos interesantes de pelota, concurso como buen jugador con mis compañeros a encuentros con otros clubs y hasta ahora siempre me tocó ganar porque procuramos que los contrarios sean más flojos y pasamos un día muy agradable el de la victoria. Dentro del negocio procuramos ser puntuales en los pagos, manteniendo el buen crédito de que siempre gozó la casa, no apuramos mucho a quien nos debe pero fiamos poco para que no se disgusten al cobrarles con el fin de no pagar, y aunque no vendamos mucho procuramos que todos salgan complacidos para después vender más (Paradero de Balbín, 13 de febrero de 1923).

Sin embargo, en 1925 la crisis económica volvió a afectar considerablemente a los miembros de la familia González emigrados a Cuba. Su hermana Cristina, residente en Coyoacán (Méjico), escribe a su hermano Joaquín, en Valdés, manifestándole su preocupación por todos ellos, debido a la crisis personal que atraviesan y al deterioro de sus relaciones, como consecuencia de su fracaso económico.

[...] A mí me da mucho corage de Antonio que no le importa ver a Elena de ese modo y sabiendo que aquello no da nada consiente en seguirla sacrificando. Insistí mucho porque viniese con nosotros una temporada a ver si con este clima y el 
descanso mejoraba, pero aunque se ve que aceptaría de mil amores no lo hace porque él no la anima. Ahora últimamente la noté tan nerviosa en el modo de escribir que hasta llegué a temer que se pusiese como muchas que vuelven a ésa, de aquella tierra, medio trastornadas. Pensé escribirte a ver si tú, que tienes algún ascendiente sobre Antonio, consigues animarlo a que volviese a España. Para lo que allí ganan en cualquier negocio que pusieran en Valdés mismo, les iría mejor, pues al menos tendrían salud y de seguir allá se acabarán en poco tiempo. Primero quise que Pedro y Manolo allá indicasen a Antonio lo necesario que era mirase lo mal que le resultaba a Elena el país y viese el modo de cambiar, pero parece que no se llevan muy bien y basta que se lo oiga a ellos para no hacerles caso y enfadarse diciendo que quieren gobernarlo [...] (Coyoacán, 27 de mayo de 1925).

\section{LAS RELACIONES CON OTROS EMIGRANTES}

En América los emigrantes trataban sobre todo con otros emigrantes. Su círculo de relaciones más íntimo estaba integrado mayoritariamente por miembros de su propia familia y por personas procedentes de Asturias, a menudo de su mismo pueblo o concejo. Esto es una norma universal de la emigración. Los vínculos de parentesco y vecindad funcionan como un mecanismo de protección del individuo, ante un entorno nuevo, desconocido y potencialmente hostil. Estos vínculos contribuyen a crear un microuniverso en el que se ejerce la ayuda y la solidaridad, en el que se controlan las relaciones, y en el que pueden reproducirse pautas de comportamiento y hábitos culturales propios de los lugares de origen (Comas d'Argemir 1990: 109).

Junto a estas relaciones y con el mismo fin de protección y ayuda mutua, los emigrantes tendrán una vida social organizada en asociaciones. En los lugares donde el número de asturianos era elevado se constituyeron centros exclusivos para ellos e incluso en torno a estos se crearon sociedades de ámbito local en las que se agrupaban los naturales de un concejo, una parroquia o un solo pueblo (López Álvarez 1993). El caso más significativo de toda América fue sin duda el del Centro Asturiano de La Habana, institución fundada en 1886 con fines de recreo, instrucción y, sobre todo, asistencia sanitaria. Para este último cometido se construyó en 1897 la Quinta de Salud Covadonga, que fue uno de los hospitales más importantes de Cuba (Álvarez Quintana 1993). La afiliación a este centro era uno de los primeros actos de los emigrantes recién llegados a la isla de Cuba. En 1913, Manuel y Pedro González, nada más llegar a La Habana, se dieron de alta en él pagando quince pesetas cada uno. En su primer recorrido por la ciudad fueron a la Quinta Covadonga, y así lo describe Manuel en su habitación del Hotel Alcázar el 25 de octubre de ese año: 
Por ésta voy a dejar, para otra [carta] seré más extenso, me duelen los hojos con la bela, porque la luz de esta habitación no funciona, acaba de salir tiu Ramón, Ángel de Cristino y el hermano Ramón. Esta tarde vino Ricardo de el Camacho, [...] nos pasió toda la tarde en trambía, nos llebó a ver la Quinta y nos gustó muchísimo, tiene más de 20 casas para toda clase de enfermedades, anduvimos por dentro de varias, hay una limpieza fenomenal, fuimos también á ver el cementerio, también ésta [es] una cosa de lo que hay que ver.

La impresión de este emigrante sobre la Quinta Covadonga es común a la de otros muchos. Uno de ellos, natural de Llanes, con pasaje para Méjico, aprovechará una escala del vapor para visitar La Habana; el 7 de abril de 1926 desde Puebla (Méjico) escribirá a sus padres contándoles su impresión:

En la Habana estuvimos el Jueves, Viernes Santo y el Sábado de gloria. A mí no me dejaban bajar [del vapor] pero Dña. Gertrudis dijo que era tía mía y entonces pude bajar. Anduvimos toda la mañana y parte de la tarde paseándonos en auto recorriendo la ciudad y pude ver que es una ciudad muy desigual, pues al lado de unas calles muy anchas y bonitas hay otras como nuestra calle de Llagar. Lo que más me gustó y lo que más vale de toda la Habana es nuestro, de los asturianos, es la "Quinta de Salud del Centro Asturiano". Esta Quinta es mayor que todo Llanes y tiene unas avenidas y unos jardines que con seguridad no desmerecerían nada al lado de los famosos de Babilonia. En ella hay toda clase de animales domésticos y no domésticos, estanques para peces, piscinas de natación, una barbería, una botica y otras muchas cosas. Ya os digo que es mayor que todo Llanes y no es exagerar, preguntarle a tía Amalia que la debe de conocer y veréis como no exagero absolutamente nada.

La pertenencia a estas sociedades era primordial para los emigrantes, pues era su único seguro frente a una enfermedad o un accidente. Es bastante expresiva la advertencia que le hace un asturiano residente en Ibor City (Tampa, Florida, EE. UU.) a otro natural de Pravia que se ha trasladado a Puerto Rico para trabajar como escogedor en la industria del tabaco:

Los recibos pagados por mí son 7 (de octubre 1914 a abril 1915) los cuales importan $\$ 10,50$. Inmediatamente debes subscribirte a otra sociedad de socorros mutuos ó de beneficencia, pues no debes estar sin una sociedad que te ampare en caso de enfermedad o accidente. Yo te aconsejo muy lealmente que jamás te abandones de tener una sociedad (29 de abril de 1915).

La advertencia fue tomada en cuenta por el emigrante, que enseguida se hizo socio de la Sociedad Española de Auxilio Mutuo y Beneficencia de Puerto Rico, institución fundada en 1883 que tenía un consultorio en San Juan y un sanatorio en Río Piedras.

En las poblaciones donde el número de emigrantes asturianos era pequeño, éstos se agruparon con el resto de los españoles. Esto fue fre- 
cuente en la Argentina, donde proliferaron círculos o sociedades españolas de ayuda mutua. Por el contrario, en Cuba, el Centro Asturiano de La Habana mantuvo la política de crear delegaciones por toda la isla, que se extendieron incluso a Florida (EE. UU. de América). Ángel González cuenta desde Aguas Buenas (Argentina), el 29 de agosto de 1921, cuales fueron los primeros pasos de la sociedad española en esta población:

Los españoles de este pueblo hemos comprado una bandera, que nos ha costado 350 pesos. Hace dos días que llegó. Creo que ya te darás una idea con el orgullo que la miramos.

Para el doce de Octubre, tendremos las fiestas de la raza, en donde podremos lucirla, hoy ya se ha nombrado la comisión para dirigir los festejos.

Ayer también hemos tenido una reunión para nombrar una directiva para un club que estamos por hacer.

La fiesta era uno de los mayores aglutinantes de los emigrantes. Las sociedades dedicaban gran parte de su esfuerzo y dinero a organizar festejos en los que los jóvenes rompían la rutina del trabajo con baile, comida y bebida abundantes. En Cuba, el Centro Asturiano de La Habana festejaba a la Virgen de Covadonga y las sociedades de ámbito local celebraban la fiesta más representativa de su concejo de origen y otras más que organizaban con cualquier pretexto. En Méjico también se celebraba la Virgen de Covadonga y en Argentina los españoles festejaban el 12 de octubre.

José González recuerda, el 24 de noviembre de 1952, las fiestas del 12 de octubre que él conoció en Rosario y Buenos Aires a comienzos del siglo $\mathrm{Xx}$ :

También los españoles celebraban sus grandes fiestas el 12 de octubre, fecha del descubrimiento de América (hoy está declarada por ley fiesta Nacional: el día de la Raza) y duraban hasta ocho días. Generalmente se hacían en las afueras de la población, en pleno campo, algunas veces bajo los árboles. Yo alcancé ir varias veces en el Rosario y una vez sola en Buenos Aires. Era algo digno de ver por el derroche que hacían, lo mismo de dinero que de buen humor y alegría. Concurría lo más selecto de la colectividad, con sus familias; eran los únicos días durante el año que quedaban abolidas las distancias entre el patrón y sus empleados. La mayoría de las grandes casas tenían su carpa y allí agasajaban a sus amistades y empleados. Había de todo, sin tasa y completamente gratis.

Estaba España entera de fiesta, pero sin mezclarse, cada provincia tenía dentro del mismo campo su lugar asignado. $\mathrm{Y}$ así, los gallegos, los asturianos, los vascos, los aragoneses, los andaluces, los zamoranos, todos se divertían de acuerdo con las costumbres de su región: con la gaita, el clarinete, la guitarra, la pandereta, las castañuelas, no faltaba nada, hasta la sartén y la llave. Bailaban, cantaban y comían todas las especialidades de su tierra. Por mucho que quisiera ex- 
plicarte hasta donde llegaba el entusiasmo, nunca podría llegar a la realidad. Recuerda tú, las fiestas del pueblo que más te llamaron la atención, multiplícalo por diez o por veinte y tendrás algo aproximado. Y también, mi querida hermana, estas costumbres sencillas y simpáticas desaparecieron para siempre. Hace muchos años que no se celebran más, solo en algún pueblito de campaña saben hacer un pequeño simulacro de lo que fueron.

\section{LAS RELACIONES CON LA FAMILIA DE ASTURIAS}

Las cartas, las fotografías y las noticias que llegan a través de los emigrantes son los medios de comunicación que unen a los emigrantes con sus familias. La fotografía tiene un papel muy relevante en las relaciones afectivas de los emigrantes con su familia y su tierra de origen (Crabiffosse Cuesta 2000: 11-97). Los retratos cruzan el Atlántico en ambas direcciones, y lo mismo las tarjetas postales con imágenes del pueblo y del Nuevo Mundo. Los retratos que llegan de América se cuelgan en espacios importantes de la casa y permiten mantener siempre vivo el recuerdo de los ausentes. Una muestra de los tres medios de unión que hemos mencionado es la carta siguiente, escrita por un emigrante de Inclán (Pravia) desde La Habana el 27 de marzo de 1908:

Querido padre: Reciví su carta por la que beo están buenos todos, mi tío y yo sin nobedad á Dios gracias.

Aquí estubo Antonio el de la Chepla á berme y me dijo que todos están buenos, tanvién me dijo que havía pasado una temporada muy alegre; según me han dicho piensa bolber dentro de dos años retirado ya, parece que le gusto Inclán. Me dice que pusieron mi retrato el día de Antroyo en la mesa y que se acordaron mucho de mí; pues yo tamvién me acordé de Udes. Aquí no acen cena ni nada para ese día así es que me estaba acordando de las bollinas que Udes. estarían comiendo ${ }^{12}$.

Oy es domingo y hay paseo de carnabal pero yo estoy de guardia [en el comercio] y no puedo ver nada pero lo veré el domingo que viene que tamvién lo hay y estoy de paseo.

Sin más por hoy, recuerdos á los de costumbre y a los que por mí pregunten; un abrazo á mis queridos hermanos y abuela y Udes. ordenen lo que gusten á este hijo que los quiere y saben no los olvida.

El mismo emigrante cuenta en otras dos cartas redactadas en Matanzas (Cuba) su impresión al recibir dos fotografías de Asturias (un retrato de la familia y una vista de su pueblo), que le sirven para seguir los cambios que alteran la fisonomía de sus hermanos pequeños y su pue-

12 Antroyo: Carnaval; bollina: pasta frita rellena de nuez con azúcar o miel, es un postre habitual en días de fiesta, también se conoce como casadielles. 
blo. Él lleva cinco años fuera de su casa y está trabajando en un comercio de tejidos y sedería. La primera carta está dirigida a una hermana y data del 19 de noviembre de 1908:

Querida hermana: Reciví tu carta por la que beo todos están buenos, mi tío y yo buenos á Dios gracias.

Palmira reciví los retratos y no sabes la sorpresa que me causó al ver que tú y Domitila estays muy crecidas y completamente diferentes a cuando yo salí de esa, al estremo que no conocería a ninguna de las dos si os viese; la que me parece que está un poco delgada es mamá, á papá yo lo encuentro igual, a José $\mathrm{M}^{\mathrm{el}}$. y Gonzalo si se les saca vien y los otros figúrate como los boy á conocer, Alfredo tiene una cara de pillo de playa, Cesar está muy gordo y Luis está muy simpático, es el que mejor salió de todos. Escuso decirte que a todos los vese.

Sin más por hoy, recuerdos á los que por mi pregunten, un abrazo á mis queridísimos padres, hermanos y agüela y dile á ella que por qué no se retrató y tu recibe un abrazo cariñoso de Braulio.

La otra carta es para su madre y data del 12 de noviembre de 1909:

Recibí las postales que están muy bien, lo conozco todo como si oy hubiera salido de esa todavía, lo único que encuentro estraño es la casa de el gaytero, pues me quedé mirándola y naturalmente no me acordaba de ninguna casa con chimenea y en ese punto menos, asta que leí la carta y vi lo que Ud. me esplicaba ${ }^{13}$. No sabe la alegría que recibí al ver la huerta y la casa, esa casa donde pasé los mejores días de mi niñez en compañía de mis queridos padres y hermanos, no hago mas que mirarlas y enseñarlas á todo el mundo.

La necesidad que tienen muchos emigrantes y muchas familias en Asturias de recibir noticias los unos de los otros es grande y se manifiesta en multitud de cartas. Cuando esa necesidad no se ve satisfecha aparece el reproche por el olvido, que es frecuente. Un testimonio muy expresivo de esto es la carta de un emigrante de la parroquia de Valledor (Allande) que trabajaba en la "imprenta de la prensa de la Habanaw:

Habana, 4 de marzo de 1864

[...]

Hermano, sabrás como el día diez y nuebe de éste entró en este puerto el correo de ésa, yo esperando una carta tuya y no pudo ser llegar a mis manos, pareze que tienes mucho frío, no puedes cojer la pluma en la mano, ó si es por otra cosa no se á que atrivoir ó que fin lo conprenda, no quisiera esplicarme

13 Las cocinas de las casas campesinas eran de leña y hogar bajo, no tenían chimenea y el humo llenaba toda la estancia. Las chimeneas comienzan a instalarse en esas casas con la introducción de las cocinas de hierro fundido, conocidas como aeconómicas" o "Bilbao". 
pero me tienes aquí pensando y cabilando, por que no sé las nobedades de esa tierra o de nuestra casa, y de consiguiente me tienes aquí confuso.

Hermano desde que recebí el certificado no he buelto á tener carta tuya. Yo todos los correos deseando la llegada cuanto antes para saber las nobedades de casa. Extraño mucho de tí. Nobedades en ésta son las de siempre, de Sto. Domingo no se sabe nada, del de Roas no sé á donde se halla, los paisanos todos están buenos, Pedro Valledor te manda memorias, Manuel del Conde está bueno, se lo dices a su madre. [...]

En las cartas no se cuentan todas las penalidades que pasa el emigrante, pues éstos son reacios a dar noticias que puedan disgustar a sus familias. Elena González, desde Rodas (Cuba) escribe el 27 de octubre de 1913, recién llegada a la isla:

Muy querida mamá: Ayer llegamos a ésta después de 10 horas continuas de tren, solamente cambiamos en Sto. Domingo y Cruces. No me mareé nada, ya ahora se trocó el refrán, el que está acostumbrado a bragas, las costuras no le hacen llagas. Sin embargo el día ha sido pésimo de impresiones sin que casi pueda explicarme el motivo, tuve muchos deseos de llorar y hoy aunque más tranquila comprendo que no debía escribir por si reflejo en la carta el estado de mi ánimo. No estoy aburrida, nada me duele, los demás también están buenos y a pesar de eso me pongo muy triste algunos ratos, pensando como es natural en los demás y en mí. Ya yo me figuraba que había de suceder esto y Uds. no les extrañará porque en los $1{ }^{\text {os }}$ tiempos todos nos quejemos algo. Si porque les diga la verdad se van a disgustar quiero saberlo para engañarlos hasta que no me acostumbre.

Entre los familiares de Asturias era habitual el temor a que los jóvenes emigrantes los engañasen y no contasen su situación real para no disgustar o defraudar a sus padres. También era frecuente la alarma cuando no llegaban sus noticias transcurrido cierto tiempo. Ante este temor se solicitaba la ayuda a algún pariente establecido en las proximidades del hijo o hermano. A una de estas situaciones responde la carta siguiente, enviada al padre de un emigrante por un primo suyo residente en Buenos Aires:

Buenos Aires, 1. ${ }^{\circ}$ de Febrero de 1918

Querido primo:

En los primeros días de Enero fui a Bernal para visitar a tu hijo Alonsín. Está trabajando de repartidor en una lechería y goza de buena saluz, al parecer está conforme en la casa donde trabaja, me dijo que el mismo día que yo lo vi te iva a escribir, debido a esto no me apuré para darte noticias de él porque supongo que te habrá escrito.

Durante nuestra conversación le comuniqué lo que hemos hablado yo y tú y le aconsejé hacer un viaje a ésa si se encontraba mal por aquí; pero me dio a entender que por ahora no piensa hacerlo, quiere seguir trabajando; sin embargo 
él tiene muchos deseos de verte a ti y a toda la familia pues me hizo muchas preguntas por todos vosotros y por el abuelo. Yo creo que no debes aflijirte por él, porque tiene saluz y es capaz para buscarse la vida, así que me parece que mientras él quiera seguir trabajando por aquí conviene dejar que él haga lo que le parezca más conveniente.

Nada más puedo decirte al respecto, si alguna otra cosa se te ofrece aquí me tienes para lo que quieras mandar.

Las cartas también pretenden ser un sistema de control de los emigrantes por parte de los padres. En las cartas que reciben desde Asturias se les recuerdan sus obligaciones y el miedo a un cambio en sus costumbres. A esta preocupación responde la carta enviada por un emigrante a su padre, desde Matanzas el 17 de diciembre de 1909, en la que acusa recibo de una fotografía de la Virgen del Carmen:

La virgen del Carmen también esta muy vien. Digale á mamá que no tenga pena que yo no soi de esos que ella dice, que á mi nunca se me olvida lo que ella me enseñó, esto es á respetar la religión y todo lo que con ella se relaciona.

De todos modos, los padres no debían fiarse mucho de las cartas y por ello durante los primeros años de estancia en América, los jóvenes emigrantes solían estar vigilados y amparados por parientes o conocidos. La estrecha relación que se daba entre los emigrantes y sus familias de Asturias provocaba que muchas de las decisiones sobre el destino y el futuro de los hijos se siguiesen tomando en Asturias. El 3 de enero de 1915 Elena González escribe a su hermano Joaquín informándole sobre el estado de sus dos hermanos, Manuel y Pedro, colocados en sendas casas de comercio, y solicitándole una decisión sobre su futuro:

Mi querido hermano: Desde hace dos días está Manuel con nosotros y no sé si se quedará definitivamente, pues pasa de cuenta el crecimiento que tiene. Es mas alto que Patixa, está delgado y cuando llegó lo encontré tan pálido, efecto del cansancio del viaje, que estuve llorando [...] horas seguidas. Ahora estoy tranquila porque lo veo sano, pero pensamos constantemente si lo dejaremos colocado ó lo traeremos para que engruese trabajando poco, comiendo bastante y respirando aire puro. Puede que se juegue el porvenir porque la casa es buena, pero si se enferma ¿no es una responsabilidad que echamos sobre nosotros? Él hace lo que le manden y está contento con la colocación que tiene, pero cuando pienso que de la cosa más sencilla se puede enfermar debido á ese mismo desarrollo me vuelvo loca porque es bueno é inocente como un santo [...]. Dice que Lilí [el patrón de Manuell le mandó volver al día siguiente, de manera que se pasaba 3 de viaje para estar con nosotros unas horas y no salir de la casa en dos años, el que pasó y el que estamos. Esto no se cómo tomarlo. Antonio le escribió una carta que te voy a copiar y suponiendo acceda á lo solicitado Uds. dirán si lo dejamos por ahora en la misma casa ó lo traemos para con nosotros. Repito que 
está sano, si no ni que preguntar había, más teniendo en cuenta las razones expuestas piensen si será conveniente ó no que trabaje tanto.

Pedro ya se fue, estuvo dos días, está bueno y comprendemos que en buena colocación, no hay que pensar en nada mejor.

Pero no solo llegan de Asturias las decisiones sobre el futuro de los emigrantes, sino que también tienen que buscarse allí las recomendaciones para mejorar su situación. La carta siguiente es una buena muestra de ello. El tío de un joven emigrante del concejo de Pravia cuenta a su hermana, madre del emigrante, la situación de su hijo Braulio. La carta no tiene lugar, ni fecha, pero sabemos que fue escrita en La Habana hacia 1905:

Querida hermana:

Como te dije en mi última fui a ver á José María para que me dijera algo sobre Braulio y acerle presente que ya abían trascurrido [los] dos años que él mismo señaló. Y me dijo que él tenía los mejores informes del muchacho y que en esa Casa estaba muy bien, que en ella aprendió a ser un buen dependiente, que él necesitaba estar un poco más tiempo en ella y que después ya podía trabajar en cualquier Casa. Que en esa Casa el Gallo tiene parando 7 muchachos, lo cual me enseñó, y que las Casas de Comercio están atestadas de muchachos parados esperando colocaciones que no ay; esto es una berdad, pero también es una berdad que Braulio ya pasa de muchacho, ya es un dependiente, y también le dije que en la Casa que está no tenía aspiraciones de ninguna clase; todo esto lo comprende él bien, pero de meterlo en el Gallo no lo beo decidido; así que si ustedes tienen alguna palanca que enchufe algo no estaría de más que la tocaran. Esto es para entrar en el Gallo, porque para otra Casa creo está bien donde está. Es cuanto tengo que decirte.

Los temas que más tratan los emigrantes con sus familias son la salud, el envío de dinero para ayudar a la casa paterna, el viaje a Asturias y el matrimonio. Estos asuntos no son un tema de la época que tratamos, sino una constante en las epístolas de los emigrantes desde mediados del siglo XIX. Una carta muy representativa de las relaciones con la familia de Asturias es la escrita el 15 de agosto de 1880 por un emigrante del concejo de Villaviciosa residente en Méjico y dirigida a una hermana:

Querida hermana, en este momento acabo de recibir tu atenta carta fecha de Julio pasado. Enterado de ella veo los disgustos que pasan en ésa por los que estoy bastante molesto y disgustado por no poder remediarlos, pues hermana, como ya les dije en otra que pensaba establecerme, lo hize desde Julio primero y estoy pasando muchos trabajos pues debo ocho mil reales que tengo que los pagar dentro de cuatro meses y no puedo de ningún modo cumplir y pienso pedir esperas pues yo si no fuese más que por mí yo lo arreglaría pero hoy lo que más me aflije sois bosotros; pero espero le digas a tu padre que no tenga miedo, que aunque hoy no puedo pero desde el 15 de septiembre en adelante les boy a mandar aunque no sean mas que diez pesos mensuales, que de cualquier modo que cuente con ellos pues si por casualidad encuentro quién me compre la casa 
la bendo y entonces les mandaré algo más y yo me buelbo de dependiente y si no que a ver cómo se arregla pues yo boy a hacer el mayor esfuerzo que pueda. Pues hermana, de lo demás no tengáis cuidado porque todabía no es mi idea el casarme ni lo haría aunque fuese, no siendo a gusto de toda la familia, de modo que entonces dentro de un año o dos a más tardar que me haga yo con mil pesos cuenta que estaré con bosotros en ésa, pues yo aquí según están hoy día las cosas y el comercio ninguna esperanza me queda y menos que no espero protección de ninguna especie pues todabía si uno tubiese quien le diese la mano tal bez se podría hacer algo pero así no es posible, así es que visto lo visto nada más que vea junto con qué pagar todo lo que nuestro padre debe y que quedemos libres pues me boy a ésa y trabajaremos todos juntos hasta que Dios quiera, pues ojalá tubiese yo ahora ochocientos o mil pesos y luego me iría para ésa pero por desgracia no tengo modo de hacerlo.

Nada más te digo por hoy hermana, hazme el fabor de mandarme a decir qué cosechas se presentan este año y sin pérdida de correo me escribes diciéndome cómo siguen nuestros padres y sin otra cosa por hoy muchos recados a todos los parientes y vecinos, al Sr. Cura y a nuestros padres muchos abrazos y muchos a nuestros hermanos, y tú recibe el cariño de este tu hermano que verte desea.

La enfermedad es una de las mayores preocupaciones de los emigrantes y de sus familias en Asturias. La enfermedad se oculta a menudo en las cartas y sólo se cuenta con grandes detalles una vez que el enfermo se ha restablecido. En muchos casos se considera que el único modo de recuperarse convenientemente es regresando a Asturias y pasando allí una temporada larga. Pero esto no se lo podían permitir todos los emigrantes. En una carta de un natural de Pravia enviada desde La Habana el 3 de julio de 1910 a la madre de otro joven emigrante se dice:

Ace pocos días estube con tu ermano Celestino y me dijo que te abía escrito diciéndote que el 20 de el corriente embarcaría para ésa tu hijo que parece que necesita ir a reponerse. Precisamente estube a bisitar a Celestino acabado de recibir una carta de la Casa donde Braulio trabaja, en la que le dicen que está muy mejorado, que bendrá dentro de pocos días para la Habana para que se embarque. Él creo que querrá bolver pronto porque de la enfermedad que padece enseguida se reponen, pero yo opino que no le dejéis venir lo menos en dos años. Celestino cuando estubo más grabe lo iba a ver con frecuencia y le decía que en un año creía ponerse bien para bolber y por eso yo te digo que [aunque] él se crea estar bien combiene en decrecer bastante para bolver.

Si la enfermedad puede con el emigrante, a casa de su familia en Asturias llegará la carta de un pariente próximo informando de su fallecimiento, del funeral y del cementerio. A veces, unos meses más tarde, llega desde América la fotografía del panteón donde reposa.

Uno de los principales objetivos de los jóvenes emigrantes es establecerse pronto para poder enviar dinero a su familia. Es una "obligación" que se les crea antes de partir y que a menudo se les recuerda por carta. 
Además no son raras las demandas directas de dinero para necesidades concretas. En una decena de cartas que tenemos de un emigrante de la parroquia de Valledor (Allande), datadas entre 1864 y 1885, se mencionan sus envíos para pagar la dote de una hermana; la ayuda para sacar a un hermano de "la suerte", es decir del servicio militar; para comprar un ternero y una vaca, y para ayudar a la reconstrucción de la casa paterna después de ser arrasada por un incendio. Los emigrantes constituyeron para las familias y para muchos pueblos de Asturias un recurso fácil para obtener dinero. Cuando se les pedía directamente, ellos consideraban una obligación responder, y en no pocos casos fueron sometidos a verdaderos chantajes. Los familiares pedían para la casa o para ellos mismos, los pueblos para sufragar obras públicas (escuelas, traídas de agua, fuentes, carreteras). La presión social a la que se sometió a muchos emigrantes exigiéndoles un enriquecimiento que no llegó nunca, provocó entre ellos sentimientos de frustración y vergüenza que fueron a menudo la causa de su "desaparición" en América e incluso de su suicidio.

Las cantidades que mandan los emigrantes de la familia González no son elevadas. Su situación nunca permitió grandes alegrías, ni como dependientes, ni más tarde como propietarios. Las pequeñas cantidades que envían las reparten entre los miembros de la familia y no parece que en este caso los jóvenes emigren con la obsesión de enviar dinero a su familia ${ }^{14}$, ni tan siquiera ésta se lo reclama, pues su situación económica no era mala. Pero no siempre es así y lo normal es que suceda lo contrario, siendo muy frecuentes las cartas en las que los emigrantes se justifican por no enviar un dinero que la familia espera ansiosamente. Un emigrante de Inclán (Pravia) escribe desde La Habana a su padre el 4 de marzo de 1907 el siguiente comentario:

El quince se embarca un hijo de el maestro de el Caliero, boy a ver si les mando uno ó dos centenes, no les mando más porque no puedo. Ya él les dirá en las condiciones que estoy, pues todo el día me lo paso en la calle. Cada mes un par de zapatos que me cuestan cinco pesos y medio, labado de ropa dos y medio, quinta [de Salud Covadonga] uno y medio, gastos extraordinarios que siempre tiene uno y la ropa que tiene uno que andar muy arreglado porque ay que

14 En una carta de Manuel González a su hermano Joaquín, en 1916, le indica el reparto de cinco centenes ( 125 ptas.) enviados por los tres hermanos emigrados en Cuba (Pedro, Elena y Manuel): "Creo [que] en este correo, o sea el 10 del próximo, embarca para esa José García, hermano de Pedro, mi maestro, estimado amigo y querido compañero, por él boy a mandar cinco centenes, 25 pts. de cada uno para papá [es decir, 75 ptas.] y 25 de Elena y Antonio para tía María. Las otras 25 pts. son 5 de cada uno para ti, son 15 pts., 5 para una misa por [el] abuelo y las 5 restantes para ayuda de la Virgen de las Hijas de María que van a comprar. 
benderle á toda la gente de por arriba y uno no se puede presentar como quiera. Bicios no los tengo porque el único que deviera tener y lo tiene todo el mundo, que es el de fumar, tampoco lo tengo, así es que ya Ud. be que si no les mando más es porque no puedo, y el sueldo creo que es poco por más que no sé lo que gano, pero me lo supongo.

El 8 de noviembre de 1908, el mismo autor de la carta anterior, ahora trabajando en Matanzas (Cuba) en la tienda de tejidos Las Novedades de Juan Fonseca y Ca., vuelve a contestar lo mismo a su familia:

Ya beo lo que me dice de la desgracia de la baca y la mala cosecha. Ud. dirá que vien pudiera yo mandarles alguna cosa. Yo si pudiera ya lo creo, pero yo no puedo. Aquí se gasta mucho y no sé lo que gano, deje ver ahora cuando se pase balance, como estoy en la casa se pasará el balance en enero.

La mayor parte de los emigrantes envía cantidades de dinero pequeñas, como corresponde a personas que nunca alcanzaron una gran fortuna y a las que incluso esos envíos les suponían un esfuerzo y un sacrificio importantes. El dinero llegaba a Asturias a través de giros bancarios y por medio de emigrantes retornados estacionalmente que lo traían en mano a las familias. Como ejemplo de estos envíos tenemos las anotaciones efectuadas por el padre de los hermanos Segundo, Filomeno y Juan Suárez, del concejo de Valdés, que habían marchado en 1905, 1906 y 1909 para Cuba, y envían a su casa las cantidades siguientes:

Cuenta del dinero que recibo de los hijos ausentes

1907, 30 de julio, recibí de Filomeno que mandó por Macrino .. 250 ptas.

1910, 31 de diciembre, recibí de Juan ............................................ 125 ptas.

1910, 31 de diciembre, recibí de Filomeno ....................................... 25 ptas.

1911, 26 de marzo, recibí de Juan ................................................... 125 ptas.

1911, 15 de diciembre, recibí de Segundo ..................................... 500 ptas.

1912, 8 de julio, mandó Juan por Celesta un billete de 25 pts. .... 25 ptas.

1913, 21 de junio, mandó Filomeno por Waldo García para su

padre y su madre dos centenos .................................................... 50 ptas.

1913, 10 de julio, mandó Juan por Celestino de Mateo para

celebrar su santo 1 centen ............................................................... 25 ptas.

1916, 7 de septiembre, mandó Filomeno para los hermanos

por su tío Rufino ........................................................................... 90 ptas.

1921, 24 de julio, mandó Filomeno a su madre por Ramón

Carreño una onza americana ...................................................... 100 ptas.

1922, 19 de julio, mandó Filomeno por Manso una onza

americana .............................................................................. 100 ptas.

1925,5 de junio, Segundo mandado por su tío Rufino ................ 135 ptas.

1928, 20 de noviembre, mandó Luisa por letra ................................ 50 ptas.

1931, 16 de abril, recibido de Juan dos billetes americanos de

10 dólares cada uno que mandó por Segundo de Dolfo.......... 100 ptas. 
El retorno a Asturias, aunque sea temporalmente, es uno de los mayores alicientes del emigrante para trabajar y ahorrar. El asunto aparece en muchas cartas. Un emigrante del concejo de Pravia escribe a su madre el 27 de abril de 1904 desde Puerto Príncipe:

Dice que pasaron las fiestas de Pascua por un lado alegres y por otro tristes porque cada bed que le mandaban mis ermanos partir un bollo que se acordaba de mí, pues no tenga pena que no tardaremos muchos años en comerlos todos juntos, me he de aplicar todo lo que pueda para poder berlos luego.

En una carta de Francisco González enviada desde Mariano Miró (Argentina) el 16 de marzo de 1913 dice:

No puedes imaginarte, querido hermano, con cuanto entusiasmo y alegría espero el día tan deseado por mí de poderles hacer una visita.

Comprendo la alegría que ustedes experimentarían al recibir la visita de uno de nosotros pero por mucha que sea creo no alcanza á la nuestra al poder ir á ése después de diez ó doce años de destierro sin sentir en ese tiempo ni una sola palabra de cariño ni tener un solo momento de descanso.

Debe ser tan alegre que hay momentos que me parece que es cierto y me hago la ilusión que estoy en ésa hasta que uno cae en la realidad y entonces bienen los momentos tristes y aburridos de la América, que por cierto son bastantes mayores que las alegrías por que no solamente uno se entristece por estar lejos de la patria y de los Seres más queridos que á uno le han dado el ser, sino que uno tiene que atravesar por situaciones muy críticas y éstas son tantas que nos tocan á la mayoría y entonces recién nos damos cuenta de lo que vale nuestra terriña y de la varvaridad que hicimos al salir de ella, pero por no pasar vergüenza, sufrimos y aguantamos, si no tan pronto llegamos á ésta nos volveríamos la mayoría.

La posibilidad de retornar al pueblo no solo depende del dinero. Cuando el emigrante llega a ser propietario de un comercio y dispone del capital necesario para volver temporalmente a Asturias, no siempre puede marchar y dejar su negocio en manos de dependientes. Solamente se irá si tiene socios o si con él está trabajando un familiar (sobrino o hermano) preparado para llevar el comercio en su ausencia ${ }^{15}$. Por eso, muchas veces, la colocación de un pariente era un favor mutuo que se hacían el emigrante establecido y el recién llegado. Ejemplos de ello aparecen en varias cartas de la familia González. En una, escrita por Manuel desde Estación Balbín (Rodas, Cuba) el 7 de octubre de 1919 a su madre, dice:

Usted no debía entristecerse por la partida de Jacinto y Ángel, ya sabe como vienen, vienen como nosotros para casa de hermanos en donde estuvimos siem-

15 El mismo proceso siguen los emigrantes de otras regiones españolas, véase W. A. Douglass y J. Bilbao (1986: 210). 
pre considerados y queridos casi como en la casa que nos criamos. Además servirá para que nosotros podamos ir por turno a verla con frecuencia, esta idea debía amortiguar casi toda la pena que le pueda producir la separación de ellos.

Otra carta, escrita por Francisco González desde Aguas Buenas (Argentina) el 23 de julio de 1920 a su primo y cuñado Antonio, en Rodas (Cuba), hace referencia a su sujeción al comercio en el que tenía nueve empleados, entre ellos a su hermano Ángel que llevaba con él unos pocos meses:

Yo tenía pensado ir este año á ver á Mamá pero con la desgracia que tuvimos el año pasado en la que murió mi querido socio me es imposible, pues de ninguna forma hoy puedo abandonar el negocio.

No creas que no pienso en el viaje, sí lo pienso, y mucho, pero cuando el destino se opone no hay más remedio que conformarse con la suerte que nos tiene reservada.

Ahora, cuando Ángel se ponga un poco más al corriente pienso dejarlo aquí con otro muchacho que tengo y entonces podré ir á dar una vuelta, pero probablemente no será antes de 3 años.

En casa creerán seguramente que no voy por no gastar dinero y no es así, pues nunca he sido con mi familia miserable y ahora menos aún y si no le pueden preguntar á Ángel y él les dirá lo que yo digo.

Hoy por hoy, el único que podría ir sin perjudicarse es [mi hermano] Ramón, pues él tiene cómo y además tiene dos socios que aunque él falte lo mismo le van á marchar los negocios, pero yo soy solo, no tengo quien le duela nada, pues hasta el socio comanditario que tenía tuve que echarlo del negocio y ya marchó para España, así que ya ves que no es por voluntad mía sino la mala combinación que se me ha presentado.

El matrimonio y la formación de una familia en América supone un alejamiento de la familia de origen. A partir de ese cambio de estado, el emigrante variará paulatinamente sus intereses y pensará más en su nueva familia. Las remesas pequeñas de dinero irán aflojando y desde Asturias ya nadie le pedirá nada. Las visitas a Asturias ya no serán primordiales, ni tan siquiera las cartas que los unían. La mujer del emigrante se convierte en su confidente y éste ya no necesita, como antes, el desahogo de contar sus cuitas, ni el consuelo que supone recibir carta de Asturias. Antonio, casado con su prima Elena y residente en Cuba, escribe el 22 de mayo de 1915, a un hermano de su mujer, viejo confidente suyo:

Me voy volviendo perezoso para escribir a pesar de tener momentos desocupados para hacerlo. Los años por un lado, el cambio de vida por otro, van echando sobre mis costillas cierta apatía que antes no sentía en mí. No creo que los años hayan efectuado una transformación así en mi manera de ser, en cambio me figuro que haya que achacárselo al de vida. ¿Sabes por qué? pues porque tengo a quien 
comunicarle las impresiones que recibo. Esa alternativa que uno tiene en este valle de lágrimas para estar triste o contento según los accidentes de la suerte.

Por todo esto, las familias solían ver con grandes reparos los matrimonios de sus hijos en América, especialmente cuando las futuras mujeres eran americanas. Normalmente los emigrantes buscaban esposa entre hijas de emigrantes españoles, aunque lo más frecuente era volver a Asturias para ese fin. Las mismas familias hacían de intermediarias para buscarles una mujer en el pueblo. Un emigrante de Barras (Allande) en La Habana se toma a broma las gestiones que está haciendo su familia para proporcionarle una novia y casarlo:

Habana, 15 de marzo 1866

[...] Hermano, en la tuya me dices algunas cosas que yo estoy inocente de ellas. La primera es la que Uría de San Salvador que tú dices que me ha traído una comisión y al mismo tiempo me haces una relación, hay cosas tan particulares, pues yo nada he sabido, como que hay mucha distancia se le abrán caído los papeles en el camino. Repito a este enlaze no tengan Uds. cuidado, en ésta no falta nada, las hay de diferentes colores y si por mujeres es á Barras no iré.

Le dirás a Antonio que si sale en bien de la suerte que saque un certificado de haber salido por inútil y que venga para ésta cuanto antes, pues en ésa nunca pasará de ser un pobre trabajador, lo que aquí si dios le da la suerte puede alcanzar alguna cosa. Sin molestar más vuestra atención darás expresiones a mis padrinos, parientes y amigos, y a la novia que vosotros me proporcionáis. [...]

En Cuba los asturianos rara vez se casaron con negras o mulatas, y en Méjico tampoco lo hicieron con "indias"; otro tema eran las relaciones sexuales. En Argentina fueron frecuentes los matrimonios entre asturianos, porque allí, a diferencia de los otros dos países, la emigración de mujeres jóvenes fue grande. Estos matrimonios tenían su razón de ser en las relaciones endogámicas de los emigrantes y también en la opinión de éstos sobre las mujeres del país. El 16 de marzo de 1913, Francisco González escribe, desde Mariano Miró (Argentina), a su hermano Joaquín, en Valdés:

Son tan holgazanas las mujeres de la América que a qualquiera asustan. Si tu estás dispuesto a mantenerlas y á vestirlas de seda no solamente 6 sino 12 te puedo llevar. Seguro de que te han de agradar de presencia, pero vas á precisar una renta de dos ó tres mil duros mensuales para poder vivir con ellas; si te convienen esas condiciones avisas y á vuelta de correo las tendrás en ésa, después no me vengas con quejas de que no las conocías. [...] Son muy elegantes y se saben presentar en cualquier lugar, pero hay que llevar los bolsillos repletos de dinero á todas horas, si no lo insultan y lo dejan en ridículo á uno en todos momentos.

Yo en pago de mis chicas molestias por enviártelas te pido una sola en ésa que sea bonita ó por lo menos que no sea fea, pues para feo basto yo, que sepa trabajar y que esté en regular posición [o] por lo menos que tenga cómo comer sin tener que trabajar mucho. 
El cambio de estado civil del emigrante era un asunto que incumbía a la familia y en algunos casos también a la sociedad comercial. De este modo, el mismo Francisco González necesita el consentimiento de sus socios para casarse, y así se lo manifiesta a su hermano Joaquín, al que le informa que ya tiene el permiso de los socios en Argentina, pero le falta el de un comanditario que vive en Oviedo, solicitándole que vaya él personalmente a esta ciudad y obtenga el permiso de ese socio:

Como ya te decía en mi anterior, pensaba casarme para el mes de Junio pero como me falta aún el permiso del Sr. Figar que vive en Oviedo no quisiera hacerlo hasta que me lo diera, por más que si no me lo da lo mismo lo voy hacer, aunque tenga para ello que arruinar mi carrera saliéndome de la casa.

Hoy no puedo volver atrás y quedarme en este pueblo así que espero no dejes de ir allí donde él vive, Cimadevilla 19, y lo veas para que consienta en ello.

Sé que mamá se opone a ello por lo mal

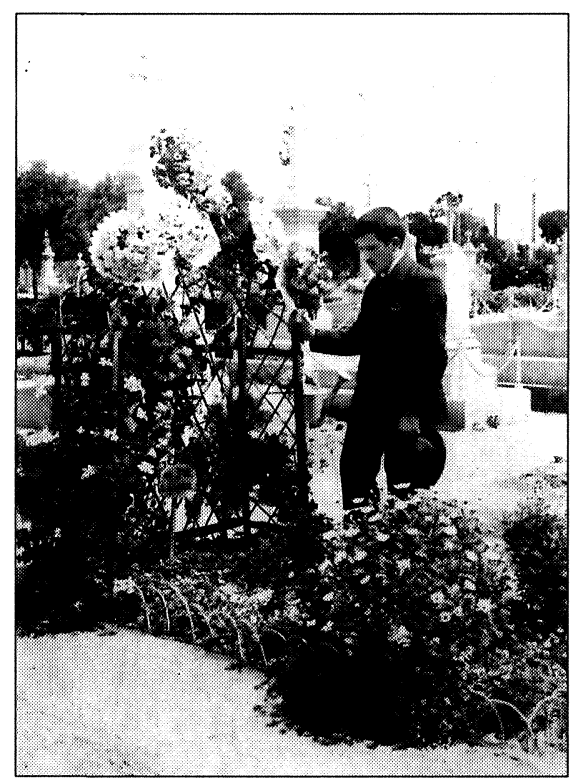

FIGURA 3.-F. Esperón, Retrato de un emigrante de Llanes junto a la tumba de su hermano, Méjico 1901. Manuscrito en el reverso: Dedico este triste recuerdo a / mis padres y hermano / Méjico, 10 de junio de 1901 / Nicolás García. Col. "El Oriente de Asturias". que la han informado, pero no deben hacer caso pues no soy ningún muchacho para no ver si me conviene y les probaré que están engañados al juzgar a mi futura Sra. en la forma que lo han hecho.

Por lo tanto, querido Joaquín, si en algo soy digno del cariño de todos Uds. no dejes de conseguirme que Figar me autorice a ello porque si no lo mismo lo voy hacer pero arruino mi carrera, pues tendría que salir de la casa, lo que estoy dispuesto, y no volver atrás (Aguas Buenas, 28 de mayo de 1915).

No fueron pocos los casos de emigrantes que marcharon para América y nunca más se supo de ellos ${ }^{16}$. Las causas de estas "desapariciones" hay que achacarlas a varios motivos: la muerte del emigrante al poco de llegar, sin que su familia llegase a saberlo nunca; su desvinculación de la familia ante el fracaso de su "aventura" americana; las desavenencias fa-

16 W. A. Douglass y J. Bilbao (1986: 206) cuentan que a fines del siglo xIx en el periódico de la asociación de emigrantes vascos de Buenos Aires, Laurac Bat, se anunciaban alargas listas de cartas sin reclamar y las peticiones de información desde Europa sobre parientes que, sencillamente, habían desaparecido". 
miliares, o el analfabetismo. Un caso desgarrador es el que cuenta José González en una carta enviada desde Buenos Aires a una hermana residente en Valdés, el 13 de septiembre de 1950, en la que rememora un viaje realizado en 1904 como representante de una casa de comercio:

Te dije que en Bahía Blanca terminaba el ferrocarril y tenía que hacer la campaña del Río Negro. Con otro viajante de distinto ramo alquilamos un carro. Llevamos cinco caballos: el cochero era argentino puro, un verdadero criollo, conocía la campaña palmo a palmo. Un día tratábamos de llegar a la proverduría de una estancia de alemanes: Guillermo Traublia, pero los caminos primitivos eran muy malos. Al pasar un arenal se empacaron y no quisieron seguir. Era en medio del desierto, allí no había poblaciones. Marchábamos días enteros y no se veía otra cosa que majadas de ovejas, tropillas de guanacos y avestruces y un montón de zorros salvajes que hacían estragos en las majadas. Un poco más lejos de donde nos quedamos empantanados, en una lomita había un rancho: paredes de barro y el techo unas cuantas chapas de zinc. Caminamos hasta allí. Nos recibió un hombre, más bien parecía una bestia. Tenía toda la apariencia de un loco. Sucio, rotero, desgreñado. En aquella cabeza jamás había tocado ni un peine ni un cepillo. Uraño, desconfiado, le contamos lo que nos había ocurrido y le pedimos nos dejara hacer noche allí. De mala manera contestó que podíamos quedarnos, pero que no tenía nada para comer. Hacía mucho frío, y queríamos calentarnos al lado del fuego. Poco a poco traté de conquistarme su confianza, le pregunté el tiempo que llevaba en el desierto, de qué nacionalidad era y sus medios de vida. Y llegamos a lo que quería contarte. Han pasado tantísimos años, nada de aquella escena se me olvidó, ni se me olvidará hasta que me muera. No sabía los años que tenía, ni cuántos estaba en el Río Negro. Era español y asómbrate, paisano tuyo, asturiano de Castropol. Le dije que también era asturiano de Luarca. Me contestó que lo había oído nombrar, pero que no conocía. Hablaba un poco de Navia y de Ribadeo. De pronto sin decir nada se levantó y se fue. Tardó más de una hora en volver. Venía acompañado de una india, tan sucia como él. Ninguno de los dos habló una palabra. La india entró a la cocina y preparó un guiso de arroz con carne de oveja, una gran porquería pero no se podía dejar, allí no estaba el Hotel de Londres de Bahía Blanca. Aquel salvaje volvió a salir y regresó con un baúl, de esos que traemos los inmigrantes cuando venimos a América. Estaba hecho pedazos, la tapa suelta, atada con una cuerda. Sacó un montón de cartas de España, 10 ó 15, todas sin abrir y me pidió que se las leyera. Eran de una hermana y de una sobrina que le llamaba: Mi querido tío. Había de todas las fechas desde 10 años atrás. Le contaban miserias y le pedían ayuda. Era rico, tenía más de 20.000 ovejas, analfaveto y borracho, el verdadero tipo de un salvaje degenerado. Como después otras veces me tocó pasar por el mismo sitio, pregunté por Manuel Alonso, así se llamaba aquel asturiano. 


\section{BIBLIOGRAFÍA CITADA}

Álvarez Quintana, C. 1993. “La quinta de salud Covadonga, 1897-1927: El hospital de los asturianos en Cuba". Ástura 9: 25-37.

Álvarez Sierra, J. [1946]. Geografía y topografía médica de Castropol. Madrid: Real Academia Nacional de Medicina.

BARREDO, A. 1925. Quince años entre asturianos. Buenos Aires.

BRUNETON-GOVERNATORI, A. y B. MOREUX. 1997. “Un modèle épistolaire populaire. Les lettres d'emigrés béarnais", en D. Fabre (dir.), Par écrit: ethnologie des écritures quotidiennes: 79-103. Paris: Éd. de la Maison des sciences de l'homme.

Carnet-Guía de Gijón: Dedicado á los viajeros entre los Puertos de América y Gijón editado por el Comercio y la Industria y patrocinado por la Delegación del Centro Asturiano de la Habana. Gijón: Talleres tipográficos La Fe, [1915].

COMAS D'ARGEMIR, D. 1990. "Emigración, etnicidad y redes de parentesco en un barrio de Tarragona", en Identidades colectivas: etnicidad y sociabilidad en la Península Ibérica: 107-129. Valencia: Generalitat Valenciana.

Crabiffosse Cuesta, F. 2000. "Fotografía y emigración a América", en J. López Álvarez (ed.), Asturianos en América, 1840-1940. Fotografía y emigración: 11-97. Gijón: Museo del Pueblo de Asturias - Fundación Municipal de Cultura.

Douglass, W. A. y J. Bilbao. 1986. Amerikanuak: Los vascos en el Nuevo Mundo. Bilbao: Universidad del País Vasco.

FABRE, D. (dir.). 1997. Par écrit: ethnologie des écritures quotidiennes, textos reunidos por M. de La Soudière y C. Voisenat. Paris: Éd. de la Maison des sciences de l'homme.

HERNÁNDEZ, E. 1997. "La identidad lingüística americana en cartas del siglo XVI", en L. Díaz Viana y M. Fernández Montes (eds.), Entre la palabra y el texto: Problemas en la interpretación de fuentes orales y escritas: 195-210. Oiartzun: Sendoa-CSIC.

LE Riverend, J. 1985. Historia económica de Cuba. La Habana: Editorial de Ciencias Sociales.

LÓPEZ ÁlVAREZ, J. 1993. "Emigración y localismo: Sociedades asturianas en La Habana". Ástura 9: 53-59.

MONGE Muley, S. 1953. Españoles en Cuba. Barcelona: Gerardo Monge Muley.

NARANJO OROVIO, C. 1988. Del campo a la bodega: recuerdos de gallegos en Cuba (siglo $X X$ ). A Coruña: Ediciós do Castro.

Quirós LinARES, F. 1993. "Cuarenta años de cartas entre Cuba y Pravia, 1909-1947». Ástura 9: 39-52.

SUÁREZ, C. 1935-1959. Escritores y artistas asturianos: Indice bio-bibliográfico. Madrid - Oviedo, VII tomos.

SZCZEPANSKI, J. 1978. "El método biográfico”. Papers: Revista de Sociología 10: 231-256. 